\title{
Sudangrass : studies on its yield, management, chemical composition and nutritive value
}

\author{
G. A. Jung \\ R. L. Reid
}

Follow this and additional works at: https://researchrepository.wvu.edu/ wv_agricultural_and_forestry_experiment_station_bulletins

\section{Digital Commons Citation}

Jung, G. A. and Reid, R. L., "Sudangrass : studies on its yield, management, chemical composition and nutritive value" (1966). West Virginia Agricultural and Forestry Experiment Station Bulletins. 524T.

https://researchrepository.wvu.edu/wv_agricultural_and_forestry_experiment_station_bulletins/664 @ WVU. It has been accepted for inclusion in West Virginia Agricultural and Forestry Experiment Station Bulletins by an authorized administrator of The Research Repository @ WVU. For more information, please contact ian.harmon@mail.wvu.edu. 
West Virginia University Libraries 



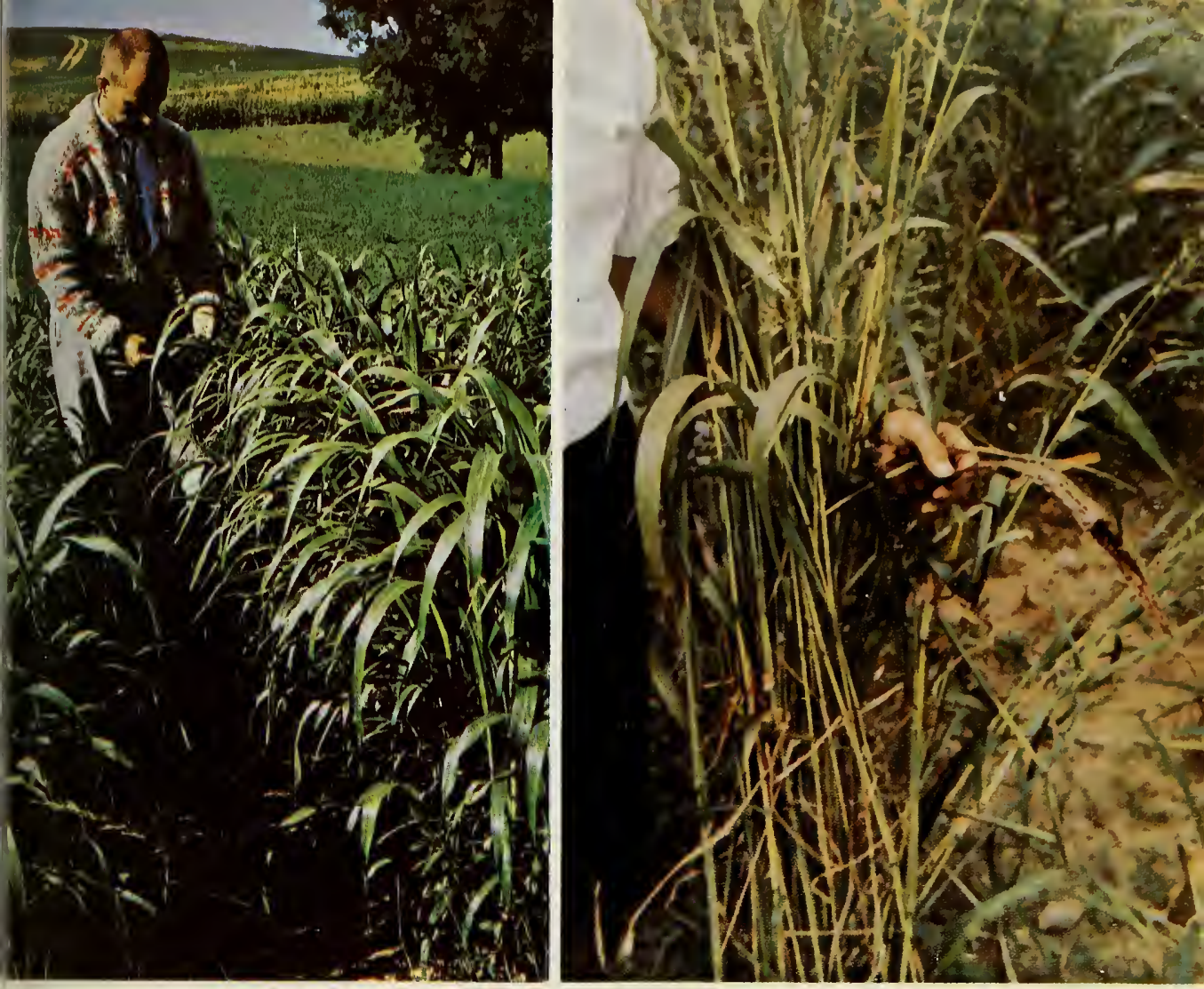

UDANARASSTERAR

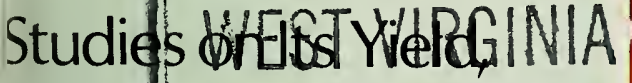
MapagewA\&WERSITY remicar Eomposition and

Nutritive Value *

3ULLETIN 524T - JUNE 1966 VEST VIRGINIA UNIVERSITY ULTURAL EXPERIMENT STATION

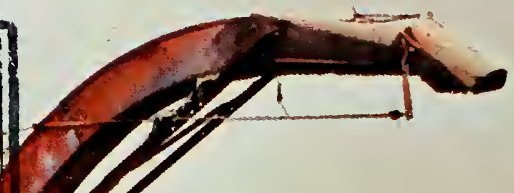

47.

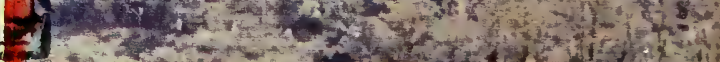

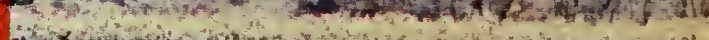

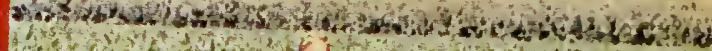

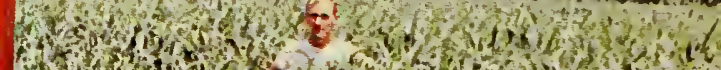

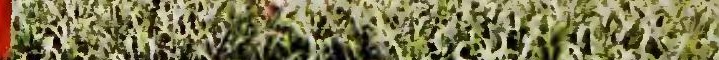

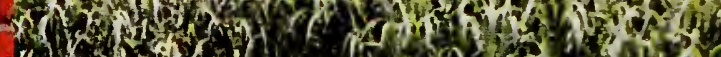

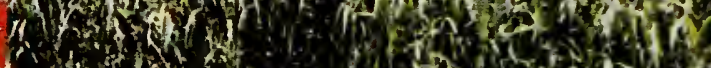

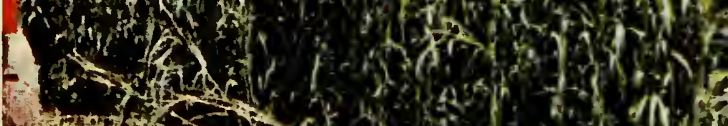

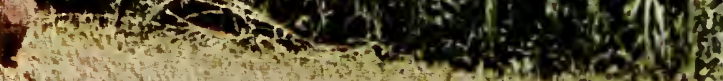

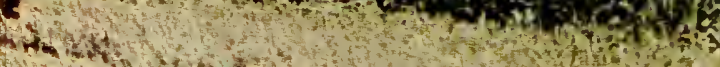

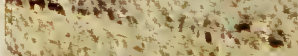

Nos? 
Digitized by the Internet Archive in 2010 with funding from

Lyrasis Members and Sloan Foundation 


\section{Contents}

Page

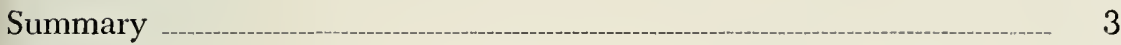

Introduction _ـ_ 5

Literature Review _-_ 6

Locations and Materials 12

Results and Discussion

Part I. Productivity and Management

Yield Potential and Environmental Adaptation 13

Resistance to Foliar Diseases 17

Hydrocyanic Acid Potential _-__-______- 21

Cutting Management

Nitrogen Fertilization ______________ 24

Part II. Nutritive Value-Animal Trials

Date of Cutting

The Significance of Intake 33

Yield in Relation to Nutritive Value

Part III. Nutritive Value-Laboratory Methods

Chemical Composition 38

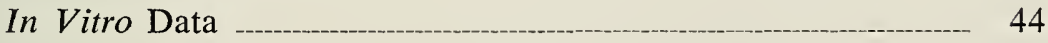

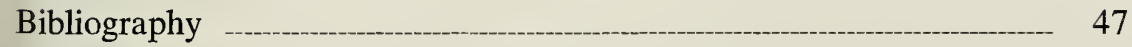

Appendix _. 51 


\title{
THE AUTHORS
}

G. A. Jung is Associate Agronomist and R. L. Reid is Associate Nutritionist in the West Virginia University Agricultural Experiment Station.

\section{ACKNOWLEDGMENTS}

The authors are indebted to Mrs. S. J. Murray for her assistance with analytical analyses; and to Mr. C. J. Cunningham, Mr. C. B. Sperow, Jr., Mr. C. B. Sperow, Sr., Mr. F. I. Taylor, Mr. C. R. Coffman, and Dr. K. C. Westover for their assistance with field plots.

\section{COVER PHOTOGRAPHS}

Photographs on the cover are described in the text of this bulletin. Picture 1 is at top left, picture 2 is at top right, and picture 3 is at bottom right. Picture 1 is described on page 13,2 on page 19, and picture 3 on page 23 .

\author{
West Virginia UNIVERSITY \\ Agricultural Experiment Station \\ College of Agriculture and Forestry \\ A. H. VANLANDINGHAM, DiRECTOR \\ MORGANTOWN
}




\section{Summary}

1. Over a trial period of four years at different locations in West Virginia, high yields of Sudangrass were obtained during a period when perennial pasture production is usually low. The most productive hybrids yielded the equivalent of 6 tons of hay per acre under optimum environmental conditions. Production was reduced by 50 per cent when environmental conditions were not favorable for growth.

2. In general, the hybrids were more productive than the Sudangrass varieties. However, there were considerable differences among hybrids; the highest yielding hybrid produced 58 per cent more dry matter than the lowest yielding hybrid under the same environmental conditions. A few hybrids were well adapted to a wide range of environmental conditions, whereas others had a narrow range of adaptation.

3. Foliar disease resistance and hydrocyanic acid potential varied with (a) the varieties and hybrids under study, (b) the level of nitrogen fertilization, and (c) environmental conditions.

4. With advance in stage of growth, dry matter yield increased for each harvest and for the total seasonal yield.

5. Increasing levels of $\mathrm{N}$ fertilization resulted in increased yields of dry matter. High levels (200-300 pounds per acre) of nitrogen increased dry matter yields 50-60 per cent over yields of grass not receiving nitrogen fertilization. Larger yield increases with increments of nitrogen were noted for Sudangrass harvested at later stages of maturity than at immature stages of growth.

6. Stage of maturity of the Sudangrass had a marked effect on both digestibility coefficients and level of intake of the grass by sheep. Digestibility of dry matter and ad lib. intake were positively correlated. The rate of decline of these factors was greatest during the early stages of growth.

7. Nutritive value of the forage was calculated as intake of digestible dry matter in relation to maintenance requirements. On this basis, harvesting Sudangrass after the early heading stage would result in a forage of little productive value. The optimum growth stage for grazing or hay or silage production would be determined by the nature of the livestock enterprise, but results indicated the advantages of early harvesting in terms of individual animal performance.

8. The relationship between nutritive criteria and date of cutting, chemical composition and in vitro digestibility coefficients was determined. Use of individual chemical components, a combination of fractions, or in vitro cellulose digestibility or gas production during the 
later stages of fermentation, was found to predict animal dry matter digestibility with acceptable accuracy. Ad lib. intake was correlated with chemical composition of the forage to a higher degree than with rates of in vitro degradation during early fermentation. Regressions utilizing either chemical composition or in vitro digestion data were found to be superior to the use of date of cutting in predicting the nutritive value of the grass. 


\section{SUDANGRASS}

\section{Studies on Its Yield, Management, Chemical Composition and Nutritive Value}

\section{G. A. JUNG AND R. L. REID \\ Introduction}

NE OF THE MOST serious limitations to efficient livestock production in West Virginia is the lack of high-quality summer pasture. The typical permanent pasture in the Appalachian region is a Kentucky bluegrass, bluegrass-white clover, or mixed grass pasture, which frequently is not subjected to a high degree of fertilization or management. The potential productive and nutritional qualities of bluegrass have been defined in a number of publications of the West Virginia Agricultural Experiment Station $(52,57,58,59,62)$. However, bluegrass tends to become semi-dormant during the hot summer months, and there is an obvious need for a supplementary forage to provide pasture, silage, or hay during the period from July to September. The sorghums, soybeans, millets, and Sudangrass have been grown as emergency forage crops in different areas of the United States with varying success. Sudangrass, an annual grass with a high ability to withstand drought and relatively poor soil fertility, has shown much promise as a forage which can fill the "bluegrass gap" in West Virginia. A series of trials was carried out during the period 1958-1962 to examine various problems in the production, management, and utilization of this grass.

Experimental work was designed to investigate the following: yield of forage from different varieties and hybrids of Sudangrass harvested at different locations in West Virginia; (2) effect of stage of maturity, cutting management, and nitrogen fertilization of Sudangrass on yield; (3) incidence of foliar disease in Sudangrass varieties and hybrids; (4) relationship of variety of Sudangrass and nitrogen fertilization to the hydrocyanic acid potential of the forage; (5) effect of stage of maturity and nitrogen fertilization on the intake, digestible nutrient content, and productive capacity of Sudangrass; (6) the application of laboratory techniques to the prediction of the nutritive quality of Sudangrass. 


\section{Literature Review}

Following the introduction of Sudangrass into the United States in 1909 , research studies were designed to establish optimum management practices for the grass and to compare its yield to that of other potentially useful annual forages. Methods of seeding, establishing, and harvesting were investigated $(1,2,8,31,35,43)$. Kiesselbach and Anderson (35) at Nebraska recorded an average yield of 3.25 tons per acre over a four-year period and determined the effect of such factors as seeding rate and stage of maturity on the chemical composition of the forage. In Iowa, Hughes and Wilkins (31) obtained an average yield of 3.54 tons of air dry hay per acre over a six-year period. Arny (2) compared the hay yield of Sudangrass to that of other emergency crops in Minnesota. Sudangrass, seeded at 30 pounds per acre, or a Sudangrasssoybean mixture (10/60 pounds), gave higher yields than oats, corn, millet, sorghum, or soybeans. In Connecticut, Brown (8) compared yields obtained from millets, soybeans, Sudangrass, or mixtures over a three-year period. Sudangrass yielded less than Japanese millet, approximately the same as the mixtures, and more than the soybeans alone or the foxtail millets. The yield of protein per acre in this study was lower for Sudangrass than for the other summer annuals. In a comparison of seeding rates and methods, Burger and Campbell (13) found that Piper Sudangrass gave a yield of 5.78 tons of dry matter per acre from three harvests a year when drilled, as against 4.85 tons when sown broadcast.

For pasturage, Ahlgren et al. (1) in Wisconsin recommended a seeding rate of 30-35 pounds per acre. Maximum production and a decreased liability to prussic acid poisoning were obtained by delaying grazing until the plants were two to three feet high. They suggested that Sudangrass planting should be limited to fertile soil; a high level of available nitrogen and a low level of available phosphorus in the soil tended to increase the plant content of prussic acid, while a low level of nitrogen and high level of phosphorus decreased it. Sudangrass was considered to be more valuable as a mid-summer pasture crop than as hay, due to the difficulty experienced in proper curing. Odland et al. (43) made a comparative study of the adaptation of Sudangrass, winter rye, winter wheat, spring oats, and Japanese millet for supplementary pasture in Rhode Island. They used different seeding times and, in the case of Sudangrass, studied the effect of cutting at four different heights, from 1 to 4 inches, on recovery of the plants from simulated heavy grazing as compared to light grazing. Sudangrass 
seeded May 20 to July 15 provided grazing from July 11 to October 1 . A June 1 planting yielded grazing from July 15 to September 7, with an average yield of 7.64 tons of green forage per acre. This was calculated to be the equivalent of 125 pasture units per acre. A twoacre unit of Sudangrass would then provide sufficient forage for five cows over a period of seven weeks. When Sudangrass was cut at different heights, best results were obtained at the one- or two-inch height. Cutting to one inch at each harvest, the yield of green forage was 8.45 tons per acre, as compared to 6 tons for the four-inch cut. This would imply that some form of rotational grazing, with heavy stocking, would be an efficient form of pasture management.

Further studies have provided information on the effect of management practices and fertilization on the yield, chemical composition, and hydrocyanic acid content of Sudangrass. Burger et al. (12) determined the effect of different cutting dates on the total and aftermath yields of four Sudangrass varieties grown under pasture and hay systems of management. They found that the pasture-management system gave markedly lower yields than a hay-harvesting system and that the relative ranking of the four varieties in hay yield did not change in relation to the cutting date. Susceptibility to disease lowered the yield of the Wheeler and Sweet varieties at later cutting dates, while the resistant Piper and Greenleaf varieties were relatively unaffected. The effect of different cutting heights on the development and yield of Sudangrass and pearl millet was investigated by Mays and Washko (38) in Pennsylvania. After the forage reached 18 to 20 inches it was clipped to 2, 4, 6 , or 8 inches above the soil and yields were recorded. The greatest dry matter yield over a season was obtained at the 2- or 4-inch stubble heights; Piper Sudangrass and the millets gave better yields at the 2 -inch height, while Greenleaf yields were greater at 4 inches. Fertilization with 200 pounds of nitrogen per acre did not change the response to cutting management, but this level of nitrogen increased yields by 50 to 60 per cent over controls receiving 500 pounds of $0-20-20$ fertilizer per acre. It was concluded that the increase in protein and TDN content, and decrease in fiber, resulting from an increase in cutting height, would not compensate for the drop in yields obtained. The influence of nitrogen fertilization in relation to cutting management was further studied by Broyles and Fribourg (10) in Tennessee. They used three nitrogen fertilization levels $(0,60$, and 120 pounds per acre) and four cutting treatments. Yields were highest by cutting at early bloom to a 4 -inch stubble, intermediate by cutting at 30 inches to a height of 10 or 6 inches, and least by cutting at 20 inches to a 6 -inch stubble. 
The order of total nitrogen production for the different cutting managements was 30-10, 30-6, 20-6, and early bloom-4. Increasing levels of nitrogen fertilization raised the yield of dry matter, percentage of nitrogen in the plant, and total production of nitrogen per acre. The optimum combination of yield and per cent nitrogen was obtained when the plants were cut back from a height of 30 inches to a 10 -inch stubble. Of the two Sudangrass varieties tested, Piper was considered superior to Sweet on the basis of yield and susceptibility to leaf blight.

The effect of stage of maturation, management and fertilization on the chemical composition of Sudangrass has been investigated by several workers $(14,18,26,27,42,48,61,64)$. As in perennial grass species, maturity is associated with a decrease in nutrient content of the plant. Rusoff et al. (61), in Louisiana, found that crude protein, ether extract, and ash content declined and that crude fiber, dry matter, lignin, and nitrogen-free extract (NFE) increased, with increasing maturity of the grass. Application of nitrogen fertilizer increased the lignin content significantly; there was a linear increase in crude protein content up to a level of 240 pounds of nitrogen per acre, and plants at this nitrogen level contained 82 per cent more protein than the controls. Crude fiber decreased from 32.0 to 30.1 per cent at the 0 - and 240-pound nitrogen levels, respectively, although there were no significant differences in fiber at the intermediate rates of application. Content of dry matter, NFE, and ash tended to decline with increasing levels of nitrogen. Cragmiles et al. (18) and Gangstad (27) noted marked differences in protein content due to stage of maturity and found that the decline in protein content with growth stage varied for leaf and stem tissue. Gangstad also reported a significant difference in protein content among varieties. The earlier work of Piper (48) and Gaessler and McCandlish (26) indicated that little change in the protein, NFE, crude fiber, ether extract, and ash content took place between the heading-out stage and the time that seeds became ripe. When Sudangrass was harvested in the vegetative stage for four cuttings, Newlander (42) found that the protein content was slightly higher, and crude fiber lower, in the first- and second-cuttings than in the third and fourth. The effect of temperature and phosphorus fertilization on composition was examined by Sullivan (64). Growth was shown to be optimal at $80^{\circ} \mathrm{F}$. and practically non-existent at $60^{\circ} \mathrm{F}$. Above $70^{\circ} \mathrm{F}$. the content of crude protein was elevated and of lignin depressed. The level of crude protein was found to be inversely proportional to the amount of phosphorus applied. In a study of the chemical composition of Sudangrass sampled after frost from three systems of summer management, 
Burns and Wedin (14) observed no significant change in per cent crude protein within each management system (three summer cuts, one summer cut, and no summer cuts) from the first to the last fall harvest. Crude fiber content, however, showed a linear increase within each management during the fall harvest period.

Factors which affect the accumulation of hydrocyanic acid in the sorghums, and the danger of cyanide toxicity to livestock, have been discussed by a number of workers. In an extensive study in South Dakota, Franzke et al. (25) noted that the factors controlling cyanogenesis in sorghums were influenced markedly by selection and breeding, and that the amount of hydrocyanic acid in plants was subject to conditions of environment, weather, soil, climate, and storage. They concluded that any factors which retarded normal plant growth might be conducive to an increase in hydrocyanic acid in later growth. Nitrogen fertilization has been shown to increase the hydrocyanic acid level in the sorghums $(11,41,45)$. In a pot culture study of the effect of different fertilizer combinations on the hydrocyanic content of Sudangrass, Patel and Wright (45) found that high nitrogen in combination with either low or optimum levels of phosphorus caused a significant increase in hydrocyanic acid content. A low level of nitrogen with either low or optimum levels of phosphorus resulted in higher concentrations of hydrocyanic acid at 20-25 days than levels obtained with low nitrogen and high phosphorus, or with optimum nitrogen and optimum or high phosphorus. High phosphorus levels tended to limit the plant content of hydrocyanic acid regardless of the amount of nitrogen used. Variations in potassium concentration had no significant effect on hydrocyanic acid concentration.

The method of processing has been found to affect the levels of hydrocyanic acid in Sudangrass. Dowell (24), Franzke et al. (25) and Swanson (66) noted that the level of acid in the plant decreased during field curing or drying, and Swanson found that ensiling Sudangrass did not decrease the amount of acid present. Krasteva (36), in a study of changes in the hydrocyanic acid content of Sudangrass as herbage, hay, or silage, reported that pasture plants contained $564 \mathrm{mg}$. HCN when $20 \mathrm{~cm}$. high and $40 \mathrm{mg}$. at the stage of milk ripeness. Hay contained $78 \mathrm{mg}$. when made in late June and $35 \mathrm{mg}$. in late July. Levels in silage were $171 \mathrm{mg}$. when made in late June and $60 \mathrm{mg}$. in early August. The hydrocyanic acid content decreased during the storage of hay, but not during the storage of silage.

Comparatively little work has been done in determining the nutritive value of Sudangrass as fed in the form of hay, silage, or pasture. Early 
work at the Iowa station (26) showed that Sudangrass hay at full bloom had an average digestible dry matter content of 64.9 per cent; palatability was considered to be high. Newlander (42), in Vermont, reported a digestible dry matter content of 70.0 per cent and intake levels by dairy cows of approximately 20 pounds per day when the grass was cut and dried at a height of 30 inches. Massachusetts workers (37) found little effect of stage of maturation on the digestibility of Sudangrass hay, although later studies by Van Wyk et al. (71) in South Africa indicated a marked effect of growth stage. The South African group reported a decline from 74.0 to 61.9 per cent in dry matter digestibility over a six-week period when the green forage was fed to sheep. Protein digestibility declined from 77.8 to 59.3 per cent. A similar decrease in the digestibility of dry matter, protein, crude fiber, NFE, cellulose, and energy from the vegetative to the heading stage has been obtained by Stallcup and Davis (63) with steers. Dawson et al. (21) examined the effect of growth stage of Sudangrass hay on the intake levels and milk production of dairy cows. Cutting at the stage of head emergence resulted in better consumption and higher milk yields than harvesting at the stage of full heading or seeds in the milk or soft dough state. A comparison of wheat, Sudangrass, and drouth corn silages with steer calves and sheep was made by Pfander et al. (46) in Missouri. The steers were supplemented with 1 to 3 pounds of concentrate per day, and average consumption was 22,22 , and 27 pounds for wheat silage, Sudangrass silage, and drouth corn silage, respectively. Digestion trials with sheep gave digestibility coefficients for Sudangrass of 56.2 per cent for organic matter, 61.1 per cent for cellulose, and 49.1 per cent for nitrogen. In a silage trial in Georgia, Miller et al. (40) found that Tift Sudangrass ensiled at the pre-boot stage gave higher milk yields than silage made at the boot stage, but they concluded that cutting for silage at the later date would be preferable due to greater yield per acre and lower ensilage losses.

Grazing experiments with Sudangrass have been carried out using a variety of criteria of animal productivity. A Texas study (27) over a three-year period showed that beef yields ranged from 76 to 263 pounds per acre, grazing days from 45 to 148 per acre, and liveweight gain per steer from 1.03 to 2.82 pounds per day. Highest beef yields were obtained from Piper and Tift Sudan, although Johnson grass and Sweet Sudan were considered to be more nutritious and palatable. Tippit and Jones (67) reported a six-year average of 309 pounds of beef per acre for Sudangrass in Texas. Hawkins et al. (28) obtained similar digestibilities for millet, Johnson grass, and Sweet Sudangrass 
grazed or fed in the green form to dairy cows or steers. A zero-grazing intake of 50 to 60 pounds per day, plus concentrates, supported a daily milk production of between 24.0 and 26.3 pounds for all three forages. In a comparison of green feeding and rotational grazing of Sudangrass, Rumery and Ramig (60) obtained markedly higher milk yields under the zero-grazing system. Olson and Evans (44) compared the productive capacity of alfalfa, sweetclover, and Sudangrass pastures in South Dakota. The cows were supplemented with a grain mixture according to their milk production and it was found that, over a ten-year period, the pounds of milk and pounds of butterfat per acre for the pasture season were higher for the alfalfa and sweetclover than for Sudangrass. The calculated average net TDN in pounds per acre over ten years was, for alfalfa, 1,917; for sweetclover, 1,965; and for Sudangrass, 1,572. The palatability and carrying capacity of the Sudan pastures was reported to be high. Dorrance (23), at Michigan, noted that Sudangrass pastures had a higher carrying capacity than sweetclover, rape, or alfalfa. During two drought summers, the Sudangrass had a carrying capacity of one cow per acre for approximately 60 days. On irrigated pastures in Washington, Van Keuren and Heinemann (68) found that Piper Sudangrass would carry ten mature sheep per acre during July and August and provide a TDN level comparable to that of high-quality permanent pasture. In Mississippi (9), Sudangrass pasture gave higher milk production per cow and greater persistency of milk production than did Coastal Bermuda or Dallis grass pasture. Total milk produced per acre averaged 4,764 pounds for Coastal Bermuda, 3,764 pounds for Dallis, and 3,529 for Sudangrass. Maryland workers (39) found that milk production by dairy cows on Sudangrass or pearl millet pastures was roughly equivalent, as was the protein and SNF content of the milk. There was, however, a marked difference in butterfat content; a level of 2.85 per cent was recorded for millet, as compared to 3.64 per cent for Sudangrass.

Other studies providing quantitative data on the nutritive value of pastured Sudangrass have been carried out by Carter et al. (16) in North Dakota with sheep, and by Baker et al. (3) in Delaware with dairy cows. The former workers investigated techniques applicable to the measurement of intake and digestibility by free-grazing animals; they noted differences in digestibility due to management by soiling versus grazing, and to season and maturity of the grass. Baker et al. compared intake and digestibility data for dairy cows grazing or fed cut Sudangrass at a pre-heading stage. During a six-year test period the consumption levels and dry matter digestibility of the grazed grass were higher than 
those of the clipped forage. These workers calculated that Sudangrass grazed before heading and without supplementation could maintain a daily milk production level of approximately 35 pounds of 4 per cent milk.

\section{Locations and Materials}

The investigations with Sudangrass and sorghum hybrids discussed in this bulletin were conducted at five locations in West Virginia (Figure 1). The sites were chosen to represent different elevations and latitudes because climatic conditions vary considerably within the State. The topographical variation in West Virginia affects annual precipitation, length of growing season, and ambient temperatures. The average annual precipitation for the five locations varies from 32 to 46 inches, and the length of the growing season varies from 140 to 180 days. Average maximum and minimum monthly temperatures and monthly

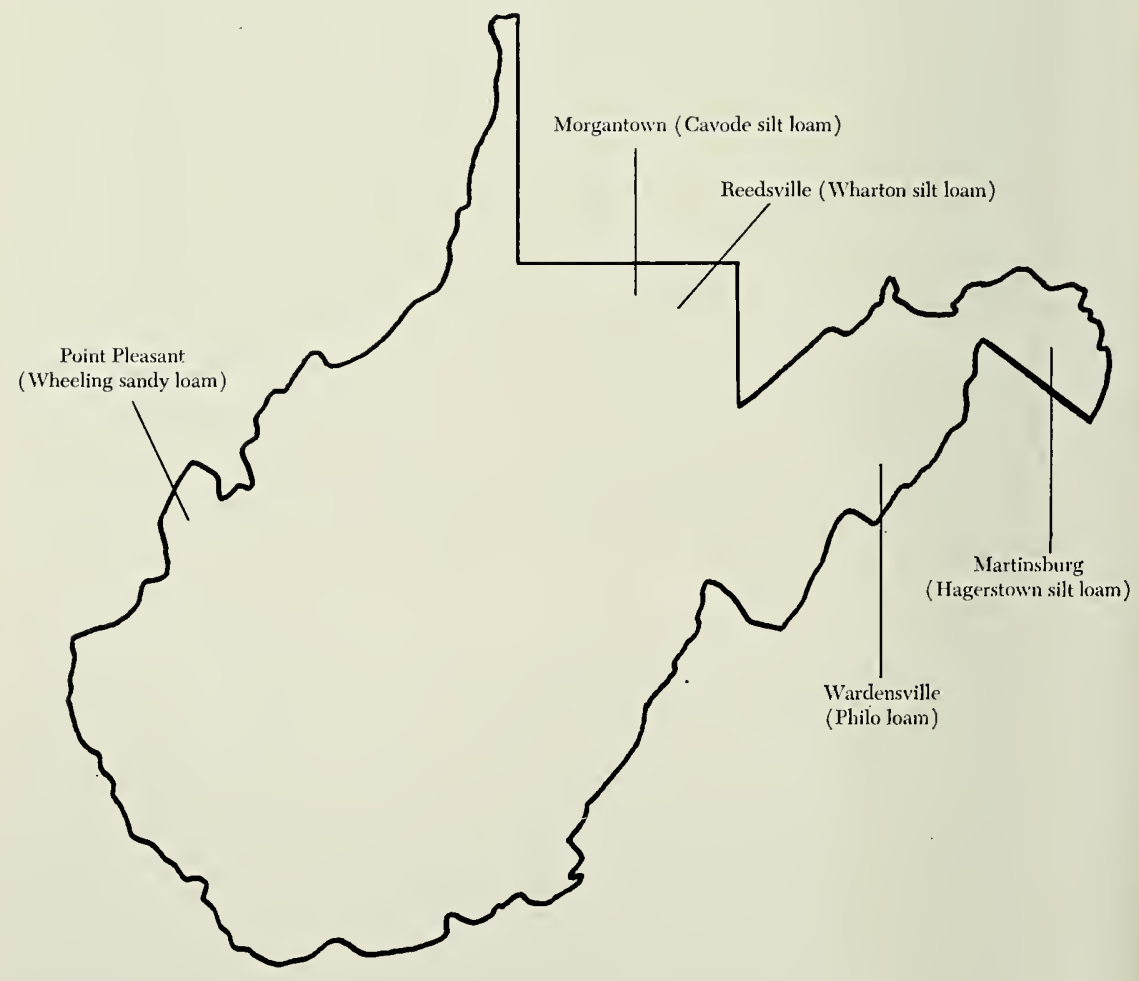

Figure 1. Location of Sundangrass trials in West Virginia. 
precipitation for each location during each study are recorded in Appendix Table 1.

An evaluation of summer annuals was undertaken to provide information on forages which might be more productive during July and August than permanent pastures. After two years' evaluation of pearl millet and Sudangrass varieties at Point Pleasant and Morgantown, pearl millet testing was discontinued because of large seasonal differences in productivity in comparison to that of Sudangrass. New materials, obtained from the U. S. Department of Agriculture and commercial sources, were screened to determine their (a) range of adaptation with different environmental conditions, (b) potential productivity, (c) growth characteristics, (d) disease resistance, and (e) hydrocyanic acid potential. Varietal comparisons were based upon a simulated pasture management system, i.e., harvesting when the leaves reached an average height of 24-30 inches ( \#1-Cover).

\section{Results and Discussion}

\section{Part I: Productivity and Management}

Yield Potential and Environmental Adaptation. Stands of Sudangrass varieties were seeded in 18-inch rows at the rate of 25 pounds per acre, after fertilizing with 100 pounds per acre of nitrogen and 500 pounds per acre of $0-8.7-16-.6$ fertilizer* and adjusting the soil $\mathrm{pH}$ to 6.0 or higher. Locations for the varietal studies were Point Pleasant during 1958-59 and Morgantown in 1960. Yields of dry matter were analyzed statistically and are summarized in Table 1. These trials show that Sudangrass can provide a high yield of forage during a period of the growing season when permanent pastures are least productive. The better varieties yielded from 3.0 to 5.0 tons of dry matter per acre, most of which was produced in July and August. Piper appeared to be an outstanding variety because of its high-yielding capacity and resistance to foliar diseases.

Vigorous growing hybrids have been developed recently from crosses between various sorghum species. The hybrid Almum was included in the 1960 trials and appeared so promising that a decision was made to compare all available hybrids. Hybrids were obtained from the U. S. Department of Agriculture and several commercial companies (Appendix Table 2). They were seeded in 18-inch rows at the rate

\footnotetext{
* Expressed in elemental form.
} 
TABLE 1

Yield of Dry Matter (Tons/A) of Sudangrass Varieties Grown at Point Pleasant and Morgantown

\begin{tabular}{|c|c|c|c|}
\hline \multirow[b]{2}{*}{ Variety } & \multicolumn{2}{|c|}{ Point Pleasant } & \multirow{2}{*}{$\frac{\text { Morgantown }}{1960 *}$} \\
\hline & $1958 *$ & $1959 *$ & \\
\hline Piper & $3.85 a b^{* *}$ & $4.97 \mathrm{a}$ & $3.17 \mathrm{~b}$ \\
\hline Greenleaf & $3.37 \mathrm{bc}$ & $4.53 \mathrm{ab}$ & $2.52 \mathrm{c}$ \\
\hline Sweet common & $3.52 \mathrm{bc}$ & $4.10 \mathrm{bcd}$ & $2.10 \mathrm{~cd} * * *$ \\
\hline Sweet 372 & $3.27 \mathrm{bcd}$ & $4.05 \mathrm{cde}$ & $1.90 \mathrm{~d}$ \\
\hline Sweet $372-\mathrm{S} 1$ & $2.92 \mathrm{~cd}$ & $3.62 \mathrm{ef}$ & $1.83 \mathrm{~d} * * *$ \\
\hline Stonerville Syn. 1 & $2.72 \mathrm{~d}$ & $4.12 \mathrm{bcd}$ & $2.05 \mathrm{~d}$ \\
\hline Stonerville Sel. & $2.12 \mathrm{e}$ & $3.54 \mathrm{f}$ & $2.01 \mathrm{~d}$ \\
\hline Georgia 337 & $3.05 \mathrm{~cd}$ & $4.83 \mathrm{a}$ & $2.04 \mathrm{~d}$ \\
\hline Common & $4.42 a$ & $4.51 \mathrm{abc}$ & $3.00 \mathrm{~b}^{* * * *}$ \\
\hline Tift & -1---- & --_-- & $3.17 \mathrm{~b}$ \\
\hline Wheeler & --1- & -------- & $3.11 \mathrm{~b} * * *$ \\
\hline Lahoma & $2.93 \mathrm{~cd}$ & $3.73 \mathrm{def}$ & - \\
\hline Almum (N. Mex.) & ----- & --- & $4.04 \mathrm{a}$ \\
\hline
\end{tabular}

\footnotetext{
*Total of three cuttings.

**Results followed by a common letter are not significantly different $(\mathrm{P}>.05)$. Comparisons may be made within each column.

$* *$ Severe foliar disease.
}

of 25 pounds per acre after fertilizing with 500 pounds of 0-8.7-16.6 and 200 pounds of nitrogen per acre, and were evaluated during 1961-62 at five locations using Piper, Tift, and Greenleaf Sudangrass as controls. All the seed was treated with a fungicide. The yields of dry matter produced in 1961 and 1962 by the Sudangrass varieties and hybrids grown at Morgantown, Point Pleasant, Wardensville, Reedsville, and Martinsburg are presented in Table 2. Yields varied considerably among varieties and hybrids, locations, and years. When environmental conditions were favorable (high temperatures and adequate moisture), 4-5 tons of dry matter per acre were produced by the higher-yielding materials. This would be the equivalent of as much as 6 tons of hay per acre. In general, climatic conditions varied considerably among locations and between years (Appendix Table 1). Therefore, the data represent yield potential under a wide range of environmental conditions. Under less favorable conditions, such as a short growing season (Reedsville, 1961) or extreme drought (Martinsburg, 1962), yields were reduced by approximately 50 per cent. It should be noted that the drought at Martinsburg was one of the most severe in the history of that area. No growth of permanent pastures occurred during the summer months; even the corn crop (grain) was a failure.

Grazer appeared to be the outstanding variety with regard to production and adaptability in these trials. It was among the highest yielders 


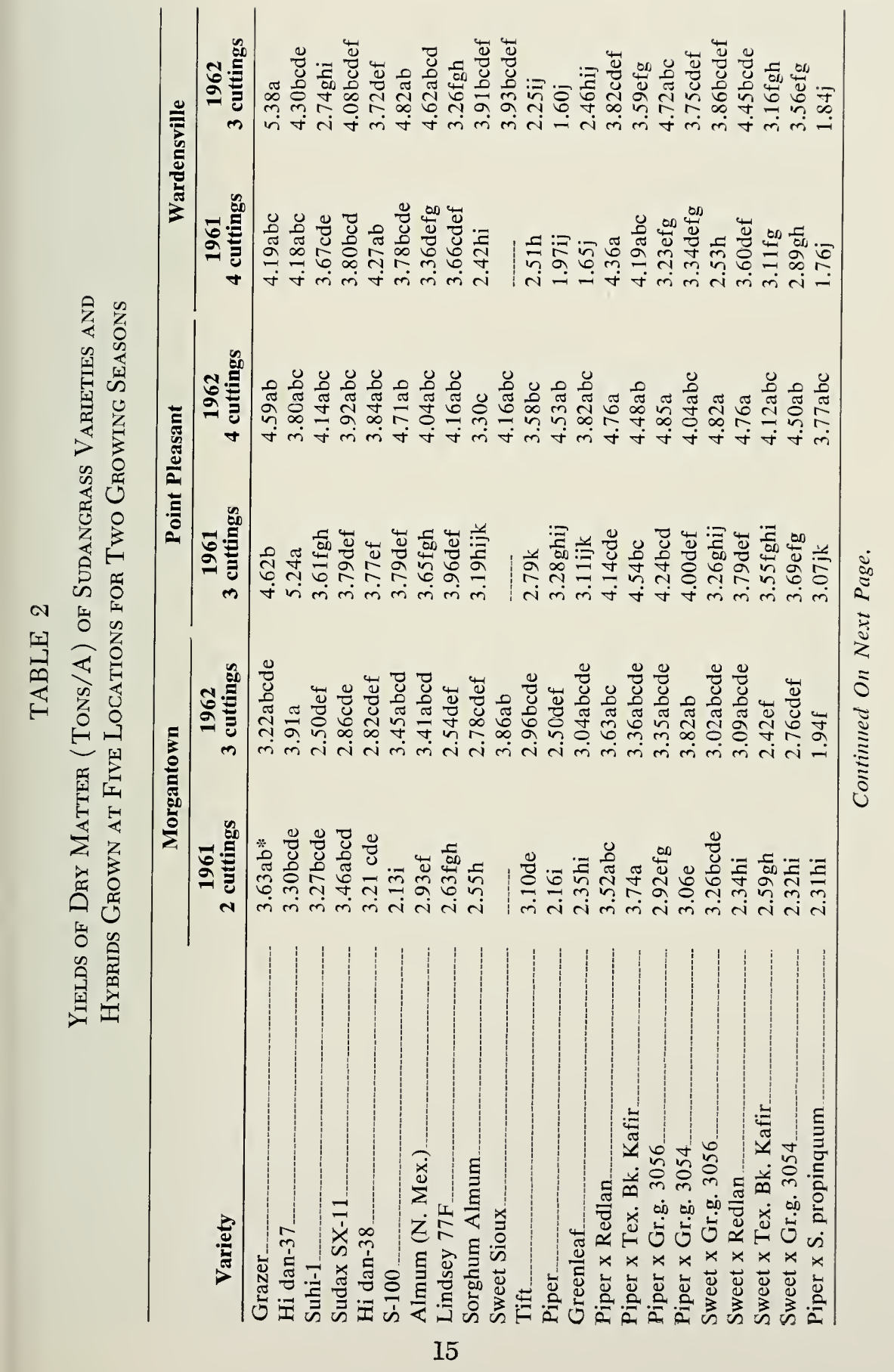




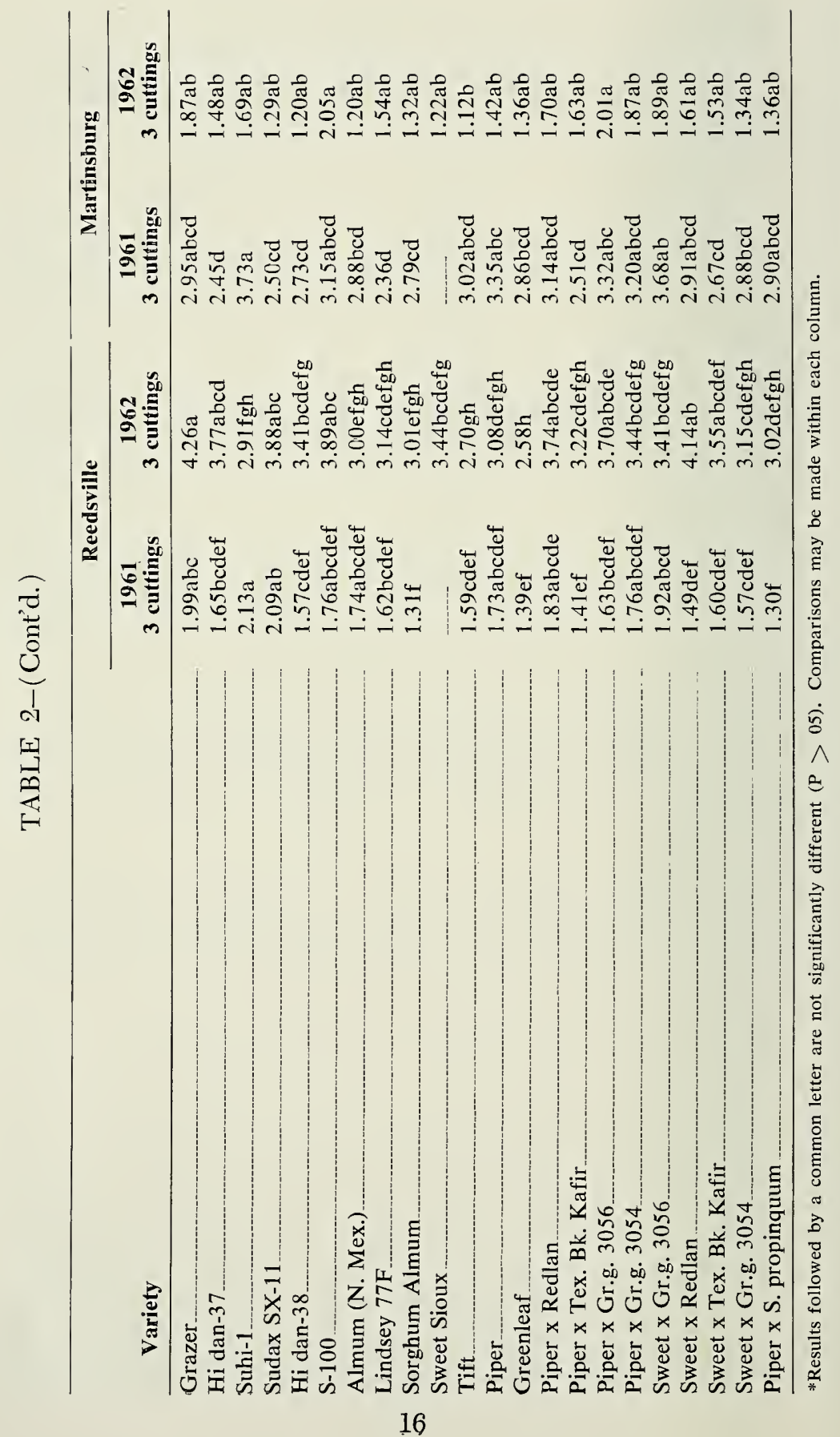


tor at least one of the two years at all locations. Other high-yielding hybrids over the two-year period at the five locations were Hi dan-37, S-100, Piper x Redlan, and Piper x Gr.g. 3056. Certain hybrids, such as Suhi-1, Sudax SX-11, Hi dan-38, Piper x Texas Bk. Kafir, Piper x Gr.g. 3054 or Sweet x Gr.g. 3056, yielded well at certain locations but apparently were not well adapted to the climatic conditions at all five locations during both years. Sweet Sioux, which was evaluated during 1962 only, was a fairly high producer that year. Other hybrids such as Sorghum Almum, Sweet x Texas Bk. Kafir, Sweet x Gr.g. 3054 or Piper $x$ S. propinquum yielded about the same or less than the three Sudangrass varieties.

When yields were expressed on a relative basis over all locations, most of the entries performed similarly for both years or performed better in 1961 than in 1962 (Figure 2). Howvever, hybrids S-100, Piper $x$ Gr.g. 3056, and Sweet $x$ Redlan generally were better adapted to environmental conditions prevailing in 1962 than in 1961 .

Many of the hybrids yielded considerably more than the Sudangrass varieties. Increased vigor accounts for some of this difference in yield potential, because regrowth following cutting was usually much faster for the high-producing hybrids than for the Sudangrass varieties. Some of the increase in yield for the hybrids might be attributed to a difference in growth type, because the high-yielding hybrids usually produced wider leaves and coarser stems (Table 3). However, an analysis of the data revealed that the dry-matter content of the Sudangrass varieties was generally higher than that of the hybrids. On the average, over all cuttings at all locations (more than 150 observations for each entry), the least succulent materials (Almum, Tift, Piper, Greenleaf, Piper $x$ S. propinquum) had a dry-matter content 10 per cent higher than the more succulent materials (Grazer, Hi dan-37, Hi dan-38, Lindsey $77 F$, Piper $x$ Redlan, Piper $x$ Tex. Bk. Kafir, Sweet $x$ Redlan, Sweet $x$ Tex. Bk. Kafir). Another aspect of the difference in growth type was observed under grazing conditions in Martinsburg when strip grazing Piper, Grazer, and $\mathrm{Hi}$ dan-37 with dairy cattle. When these varieties were grazed at a moderate stocking rate, Piper was grazed to the soil surface, while approximately 8 to 12 inches of stem stubble were left of Grazer and Hi dan-37. With a heavy stocking rate, all three varieties were grazed to the ground. Further animal studies are needed to determine the relationship between growth type and nutritive value.

Resistance to Foliar Diseases. Bacterial stripe, Pseudomonas andropogoni, bacterial streak, Xanthomonas holcicola, and leaf blight, Helminthosporium turcicum, are the most common diseases which infect foliage 

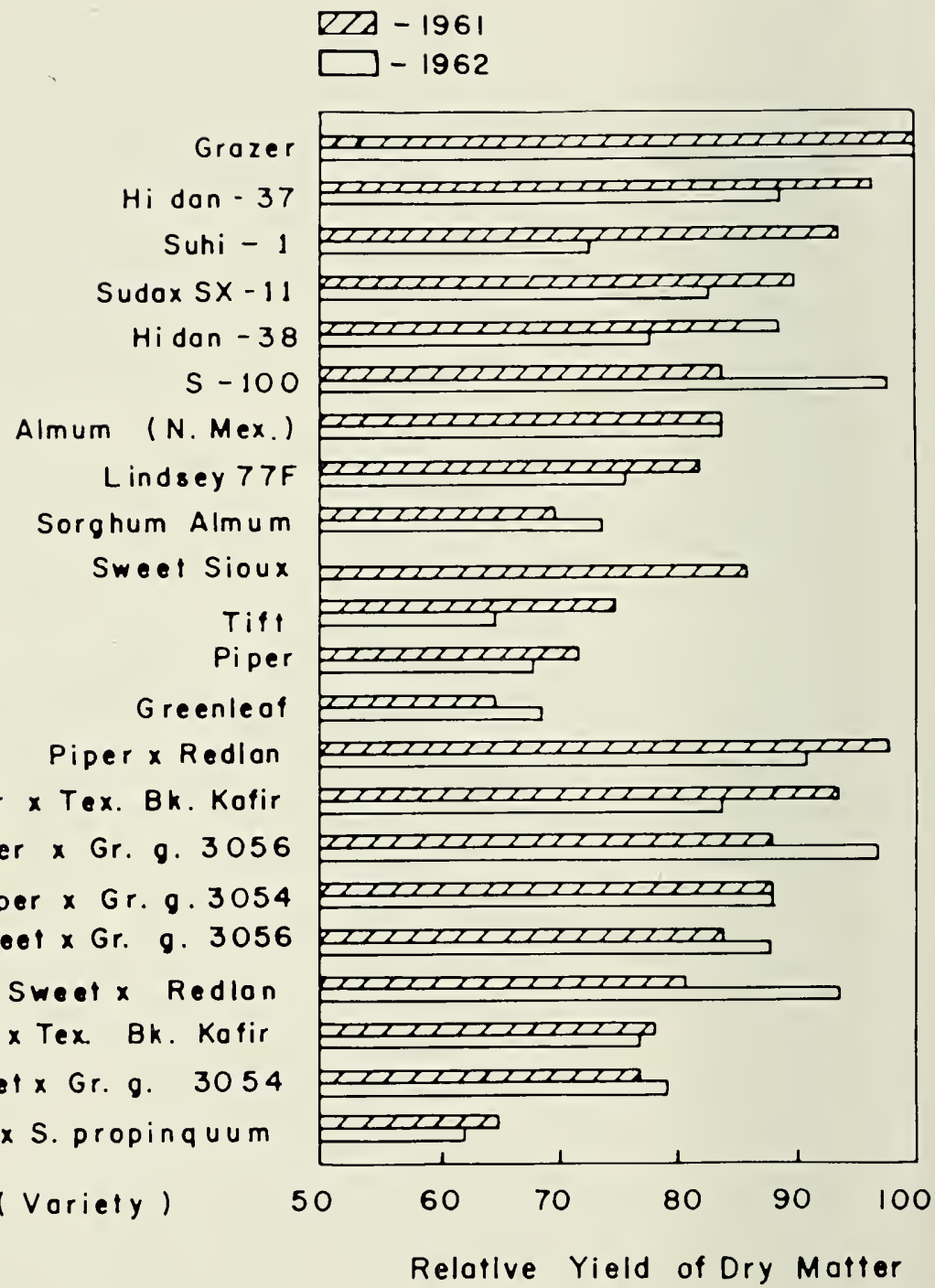

Figure 2. Relative dry matter yields of Sudangrass varieties and hybrids during 1961 and 1962 (average of five locations).

of the sorghum species in West Virginia. The prevalence of these diseases is affected by the genetic resistance of the plants to the diseases, climatic conditions, and cultural practices. These diseases destroy leaf tissue and retard plant growth when infection is severe. Whether they affect the nutritive value of the forage is not well understood. 
TABLE 3

Leaf and Stem Measurements of Sudangrass Varieties and Hybrids Grown at Morgantown *

\begin{tabular}{|c|c|c|}
\hline Variety & $\begin{array}{l}\text { Max. Leaf Width } \\
\text { (in.) }\end{array}$ & $\begin{array}{c}\text { Max. Stem } \\
\text { Diameter (in.) }\end{array}$ \\
\hline Grazer & 1.75 & 0.50 \\
\hline Hi dan-37 & 1.75 & 0.38 \\
\hline Suhi-1 & 1.25 & 0.25 \\
\hline Sudax SX-11 & 1.50 & 0.44 \\
\hline Hi dan-38 & 1.75 & 0.56 \\
\hline S-100 & 2.00 & 0.38 \\
\hline Almum (N. Mex.) & 1.19 & 0.31 \\
\hline Lindsey $77 \mathrm{~F}$ & 1.75 & 0.56 \\
\hline Sorghum Almum & 1.00 & 0.31 \\
\hline Sweet Sioux & 1.75 & 0.50 \\
\hline Tift & 1.00 & 0.25 \\
\hline Piper & 1.00 & 0.19 \\
\hline Greenleaf & 1.00 & 0.25 \\
\hline Piper x Redlan & 1.62 & 0.56 \\
\hline Piper x Tex. Bk. Kafir & 1.75 & 0.44 \\
\hline Piper x Gr.g. 3056 & 1.00 & 0.25 \\
\hline Piper x Gr.g. 3054 & 1.19 & 0.38 \\
\hline Sweet x Gr.g. 3056 & 1.06 & 0.25 \\
\hline Sweet x Redlan & 2.00 & 0.50 \\
\hline Sweet x Tex. Bk. Kafir & 2.25 & 0.44 \\
\hline Sweet x Gr.g. 3054 & 2.00 & 0.38 \\
\hline Piper x S. propinquum & 1.25 & 0.50 \\
\hline
\end{tabular}

*Fertilized with $200 \mathrm{lb}$. N/A.

Estimates were made each year at each location of the severity of foliar diseases (\#2-Cover) with ratings ranging from disease free to severe infection (more than 60 per cent leaf surface infected), and a summary of these observations is presented in Tables $I$ and 4 . No attempt was made to estimate the severity of specific foliar diseases. Severity of disease infection was affected by variety, climatic conditions, and level of nitrogen fertilization. Disease infection during this study was not of importance except in late summer. Observations in Morgantown in 1960 (Table 1) revealed that Sweet common, Sweet 372-S1, common, and Wheeler were less resistant to foliar diseases than were seven other varieties of Sudangrass. When Sudangrass varieties were compared with the hybrids over three levels of nitrogen fertilization, Hi dan-37, Almum (N. Mex.), Sorghum Almum, and Piper x Texas Bk. Kafir were found to have a high level of disease resistance (Table 4). The hybrid Piper x S. propinquum had much less disease resistance than the other materials. Piper and the hybrid Sweet Sioux also had less 


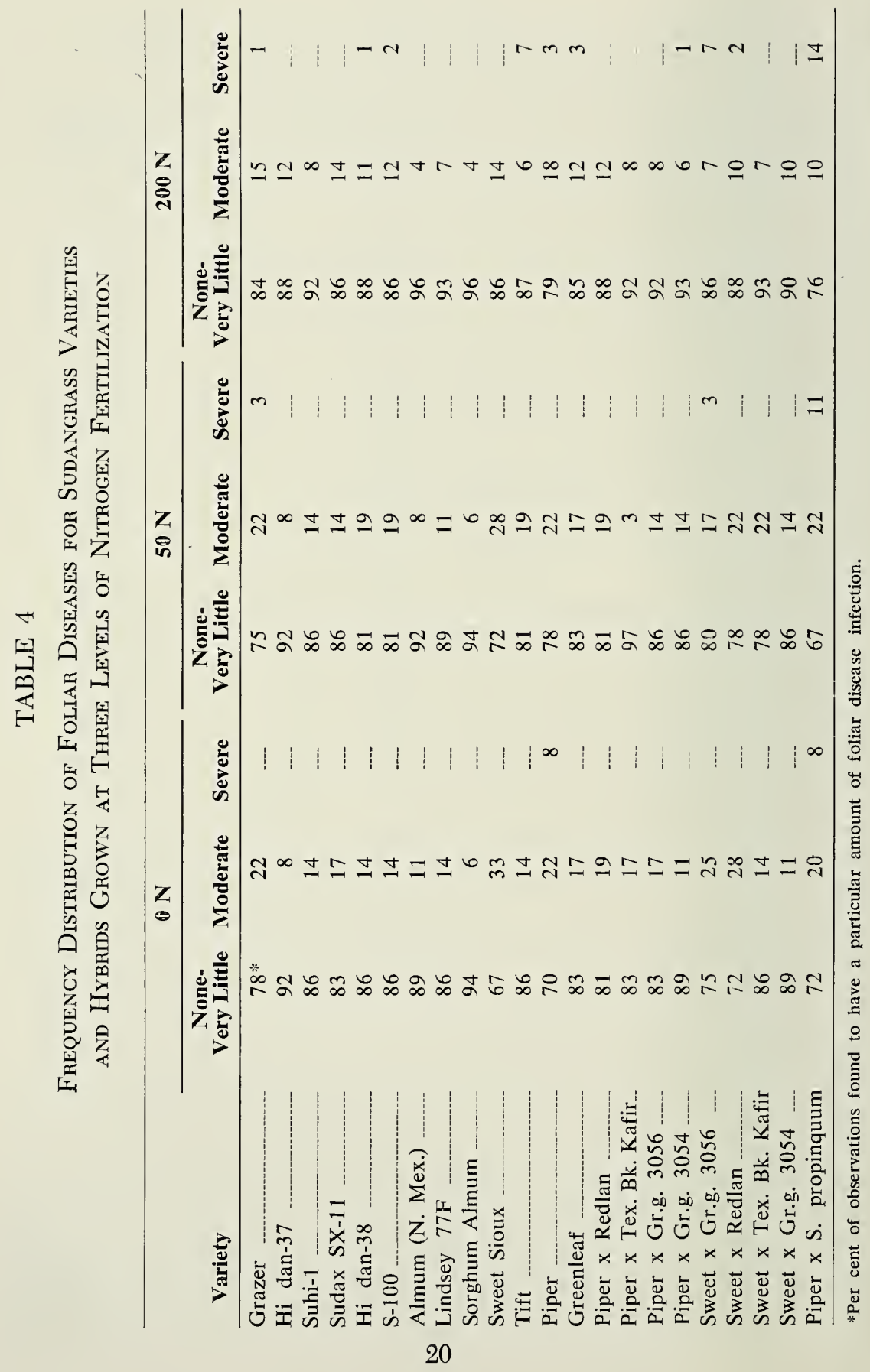


disease resistance than most varieties or hybrids. Severe infections, when present, were most prevalent on Piper x S. propinquum, Piper, Sweet $x$ Gr.g. 3056, and Tift in decreasing order of frequency.

On the average, 82.5 per cent of 774 observations made on the unfertilized Sudangrass varieties and hybrids indicated that there was either no disease, or a very low level of infection. The proportion of observations in this group increased to 83.1 per cent with the 50-poundper-acre application of nitrogen fertilizer and to 88.2 per cent with the 200-pound-per-acre application of nitrogen.

Hydrocyanic Acid Potential. Since the introduction of Sudangrass into the United States, agronomists and animail scientists have been concerned with the content of the glucoside dhurrin in this plant. Although it is known that a high dhurrin content results in hydrocyanic acid poisoning, very few studies have been concerned with determining the toxic concentration of dhurrin. After examining more than 500 samples in a hydrocyanic acid poisoning study, Boyd et al. (7) concluded that hydrocyanic acid potentials between 800 and 1,000 ppm (dry matter) were dangerous and those above $1,000 \mathrm{ppm}$ were very dangerous. However, since poisoning is also related to the amount of forage consumed, Boyd's criteria can only serve as a guide.

Hydrocyanic acid potential for pieces of green leaf tissue of Sudangrass varieties and hybrids was determined during 1961-62 using a modification of the technique described by Hogg and Ahlgren (29), and the data are presented in Table 5. The varieties differed considerably in their hydrocyanic acid potential. Suhi-1, Sudax SX-11, Almum (N. Mex.), and Sorghum Almum appeared to have higher hydrocyanic acid potentials than the other materials tested. These varieties sometimes had high hydrocyanic acid potentials even when grown under a low level of nitrogen fertilization. Hybrids which generally contained low hydrocyanic acid potentials were $\mathrm{Hi}$ dan-37, Hi dan-38, S-100, Lindsey $77 \mathrm{~F}$, and Sweet Sioux. The Sudangrass varieties and the hybrid synthetics (U.S.D.A. materials) generally contained a low potential for hydrocyanic acid production.

In a two-year management study with Piper Sudangrass (33) which included levels of nitrogen fertilization from 0 to 300 pounds per acre and growth stages from 12 inches to full bloom, higher concentrations of hydrocyanic acid were recorded for the higher levels of nitrogen and younger growth stages. However, in this study Piper never contained a dangerous hydrocyanic acid potential. Soil moisture was adequate in both years, whereas drought conditions at Morgantown in 1962 (Appendix Table 1) may explain why higher levels of hydrocyanic acid were 


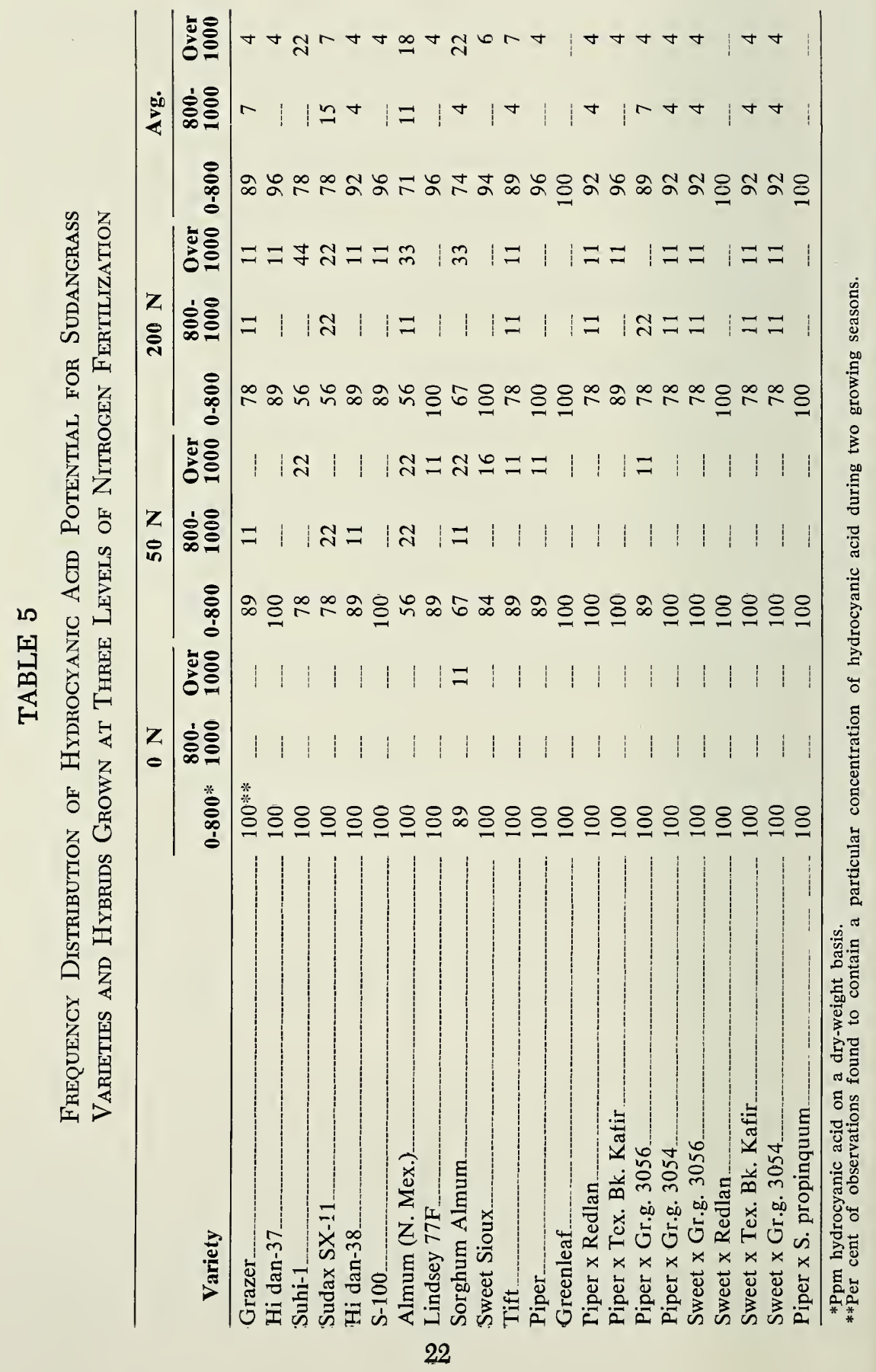


detected for Piper in the latter study. Other investigators have shown that moisture stress is directly correlated with hydrocyanic acid potential.

The influence of nitrogen fertilization on hydrocyanic acid potential was considerable. With no nitrogen fertilization, 99.5 per cent of 390 observations were found to have a safe hydrocyanic acid potential while this percentage decreased to 90.8 for the 50 pound per acre level and 82.0 for the 200 pound per acre level of nitrogen fertilization. This would be of sufficient importance to consider split applications of nitrogen for this reason alone.

Cutting Management. Piper Sudangrass was seeded in a solid stand at the rate of 25 pounds per acre in 1960 and 1961 at Morgantown after fertilizing with 500 pounds per acre of $0-8.7-16.6$, and $0,50,100,200$, or 300 pounds per acre of nitrogen. The first growth was cut at the head emergence stage of growth ( $\# 3$ cover) to permit uniform establishment. An average yield increase of 180 per cent based on 40 observations was obtained for the second harvest over the first harvest, when harvesting took place at the head emergence stage of growth. Tiller counts indicated that the stands thickened following the first harvest and this increase in tiller numbers was greatest at the higher levels of nitrogen fertilization.

The aftermath growth was harvested at five stages of growth--12, 18, and 24 inches, head emergence, and full bloom. The average aftermath yield per harvest and total seasonal dry-matter yield for each management is presented in Figure 3. The yield per cutting (2-yr. avg.) increased with an advance in maturity and the greatest increment in yield between growth stages was obtained between the 24-inch and heademergence stages of growth. Total seasonal yields generally increased with each advance in maturity, but the smallest yield increment between growth stages was obtained between the 24-inch and head-emergence stages of growth. The difference in magnitude between the single cutting and total yield in relation to the 24-inch and head-emergence stages of growth might be explained on the basis of length of the growing seasons. The average number of days before harvesting the 12-, 18-, 24-inch, head-emergence, and fullbloom aftermath was 17, 23, 29, 42, and 61, respectively. The two growing seasons varied in length considerably. Thus, the 1960 season permitted two 24-inch aftermath harvests and one head-emergence harvest, with each management having an additional 12 inches of growth at the end of the growing season (Table 6). In 1961 only one aftermath harvest at the 24-inch and head-emergence stages of growth was possible, with approximately 15 and 3 inches of regrowth remaining at the end of the season on the 24-inch and head- 
TABLE 6

Number of Aftermath Harvests Obtained for Piper Sudangrass at Morgantown During Two Growing Seasons"

\begin{tabular}{lcccccc}
\hline & \multicolumn{2}{c}{1960} & & \multicolumn{2}{c}{1961} \\
\cline { 6 - 7 } \cline { 5 - 6 } Stage of Growth & $\begin{array}{c}\text { No. of } \\
\text { Cuttings }\end{array}$ & $\begin{array}{c}\text { Residual } \\
\text { Growth (in.) }\end{array}$ & & $\begin{array}{c}\text { No. of } \\
\text { Cuttings }\end{array}$ & $\begin{array}{c}\text { Residual } \\
\text { Growth (in.) }\end{array}$ \\
\hline 12 in. & 4 & 0 & & 2 & 4 \\
18 in. & 3 & 0 & & 1 & 15 \\
24 in. & 2 & 12 & & 1 & 15 \\
Head emergence & 1 & 12 & & 1 & 3 \\
Full bloom & 1 & 4 & & 1 & 0 \\
\hline
\end{tabular}

*First cutting taken at the head emergence stage of growth.

emergence plots, respectively. Therefore, based on average yields per cut, 3.12 and 2.73 tons per acre of aftermath would be expected in 1960 for the 24-inch and head-emergence managements respectively, while 2.00 and 2.37 tons per acre would be expected for the respective managements in 1961. It is obvious that the length of the growing season favored the 24-inch management in 1960 and the head-emergence management in 1961. Thus, the difference between years would account for the large single cutting and small total yield difference between the two growth stages.

Nitrogen Fertilization. Nitrogen fertilization had a pronounced effect on the individual cutting and total harvest yields of Piper Sudangrass harvested at five growth stages and fertilized with urea at the rate of $0,50,100,200$, or 300 pounds of nitrogen per acre (Figure 3 ). The average increase in total yield for all managements was 22, 35, 47 and 61 per cent for $50,100,200$, and 300 pounds per acre of nitrogen, respectively, over the yields of the unfertilized treatments. The results also indicate that dry-matter yields were increased more with nitrogen fertilization when the Sudangrass was harvested at later stages of maturity. Increases in total dry-matter yields as a result of fertilizing with 300 pounds per acre of nitrogen were 53,56,61, 66 and 68 per cent for the 12-, 18-, 24-inch, head-emergence, and full-bloom harvest treatments, respectively. In addition, nitrogen fertilization tended to compensate for maturation with regard to yield. In several instances, less mature forage grown under high levels of nitrogen produced a yield equal to that of more mature forage grown under lower levels of nitrogen.

Sudangrass varieties and hybrids grown at Morgantown, Point Pleasant, and Wardensville during 1961-62 were seeded in 18-inch rows, after fertilizing with 500 pounds of 0-8.7-16.6 and with urea at the rate of 0,50 , or 200 pounds of nitrogen per acre and harvested whenever the forage reached a height of 24-30 inches (Tables $7,8,9$ ). In general, 


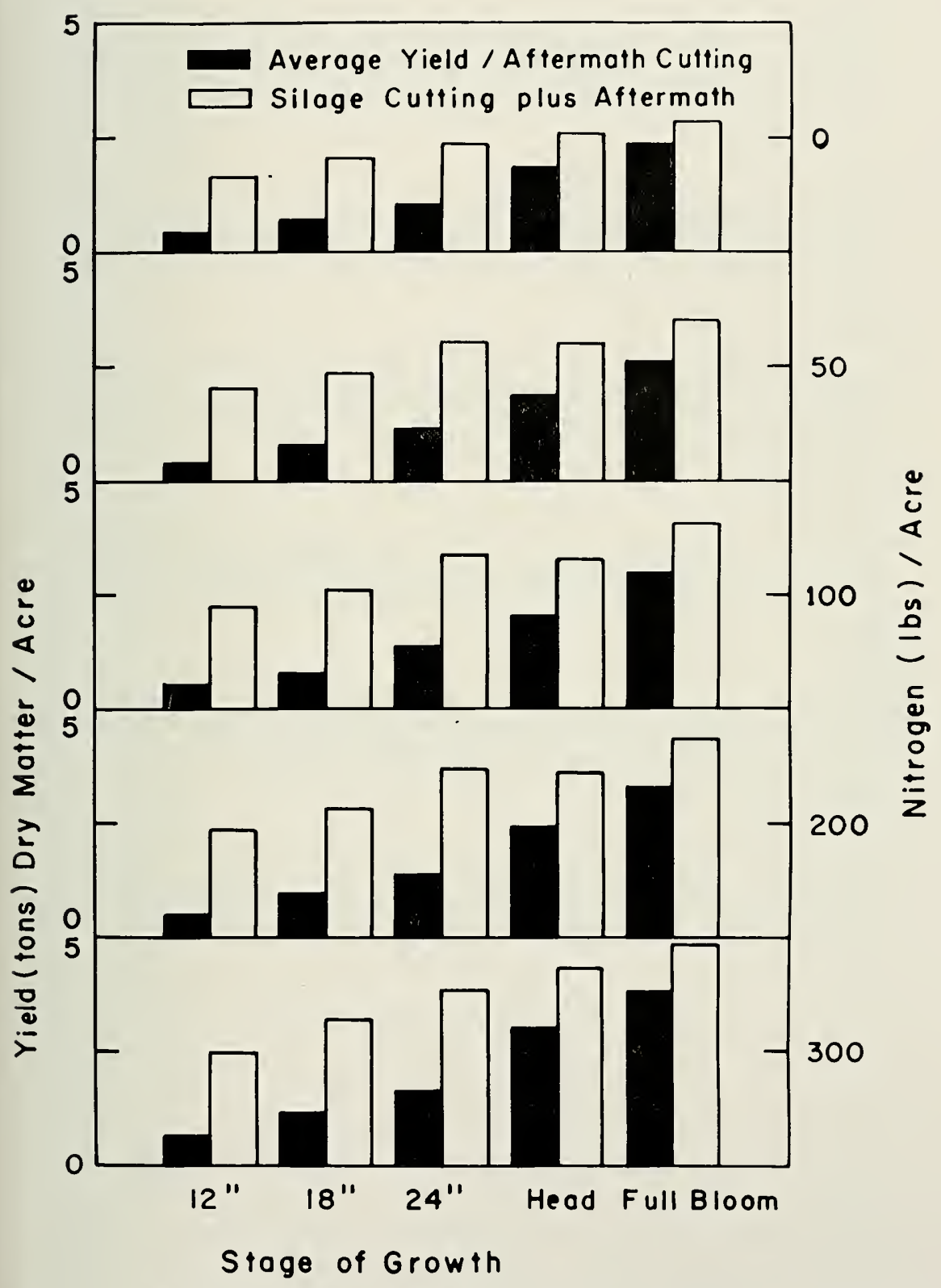

Figure 3. Dry matter yield of Piper Sudangrass grown at five levels of nitrogen and harvested at five stages of growth. 


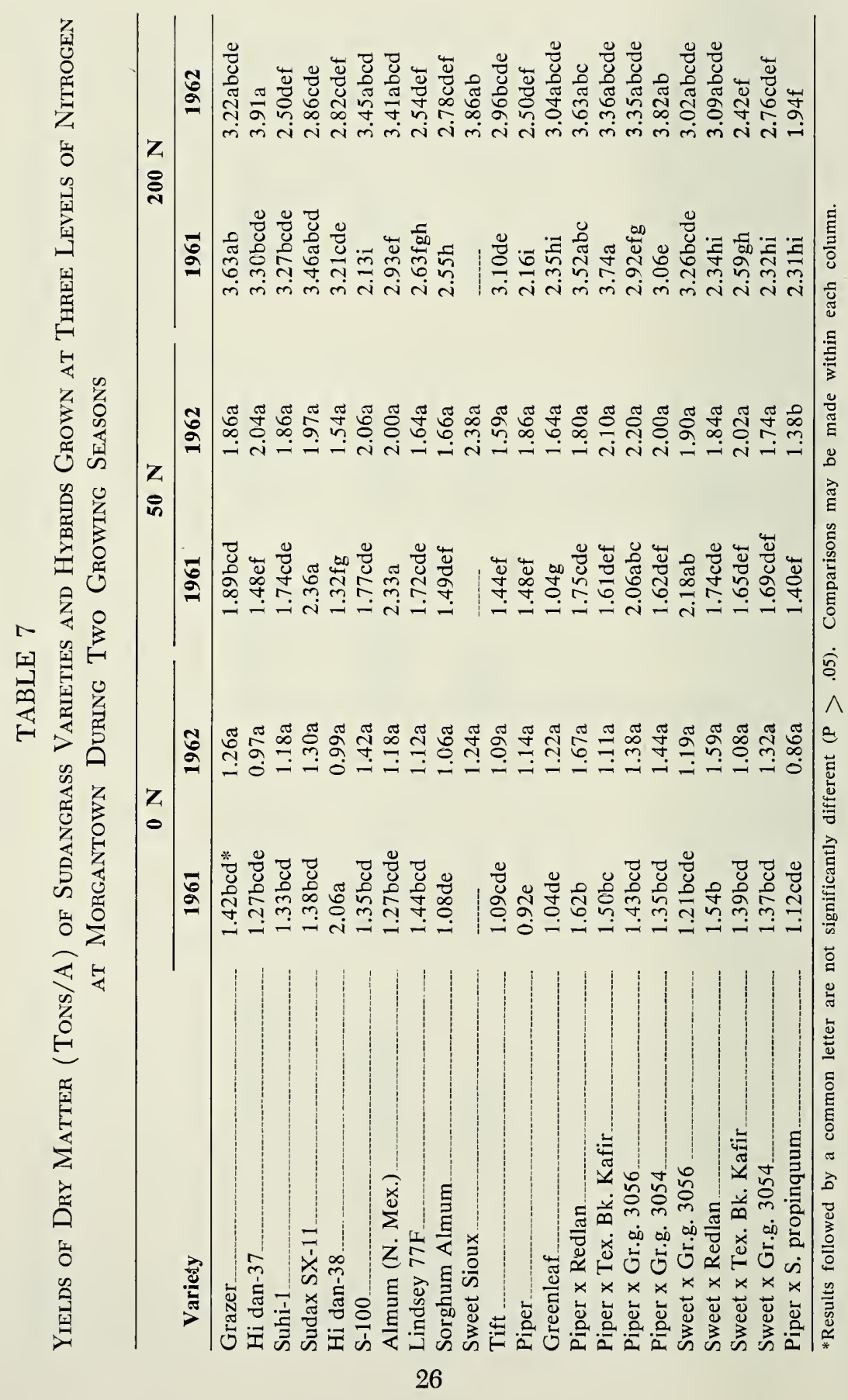




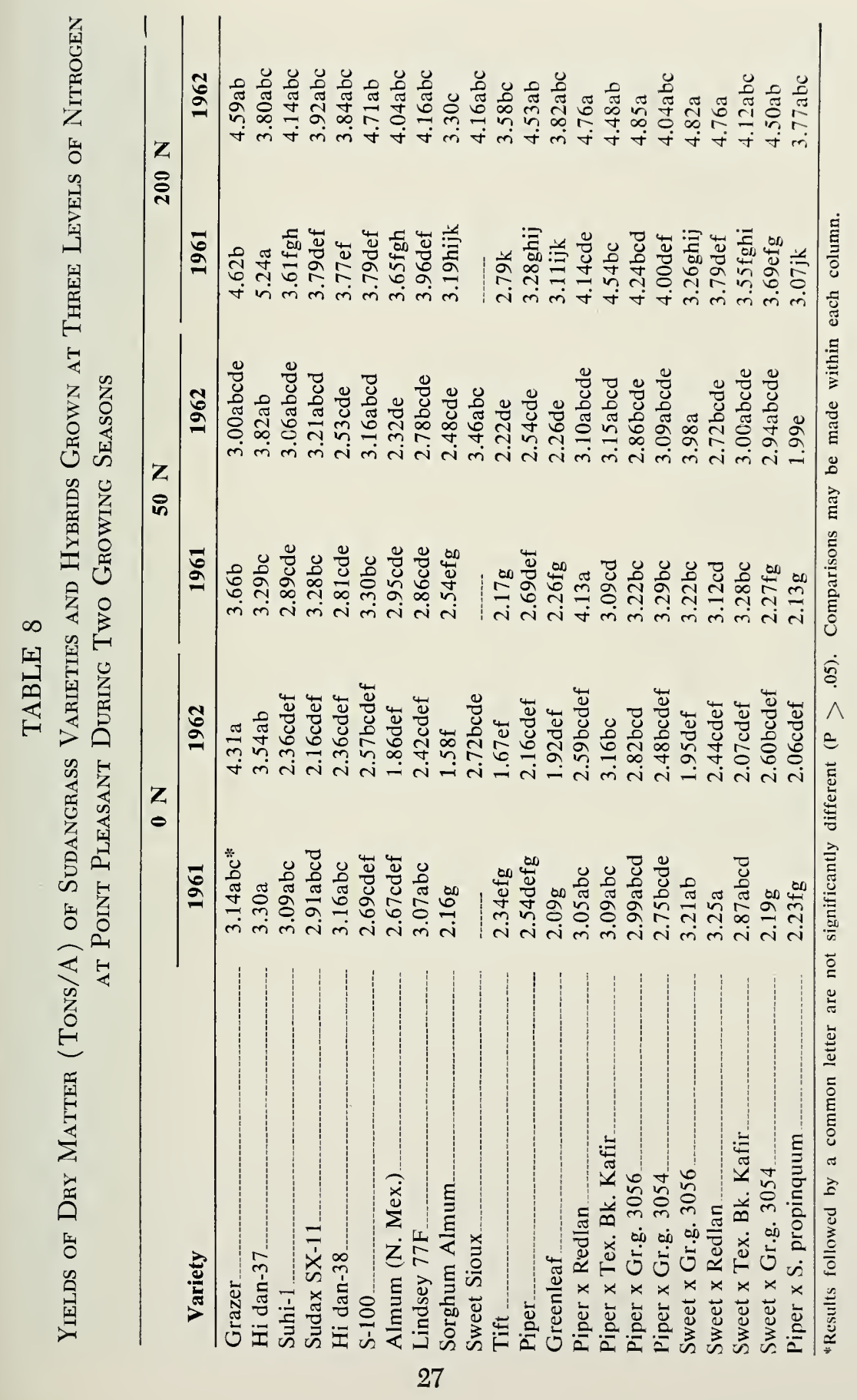




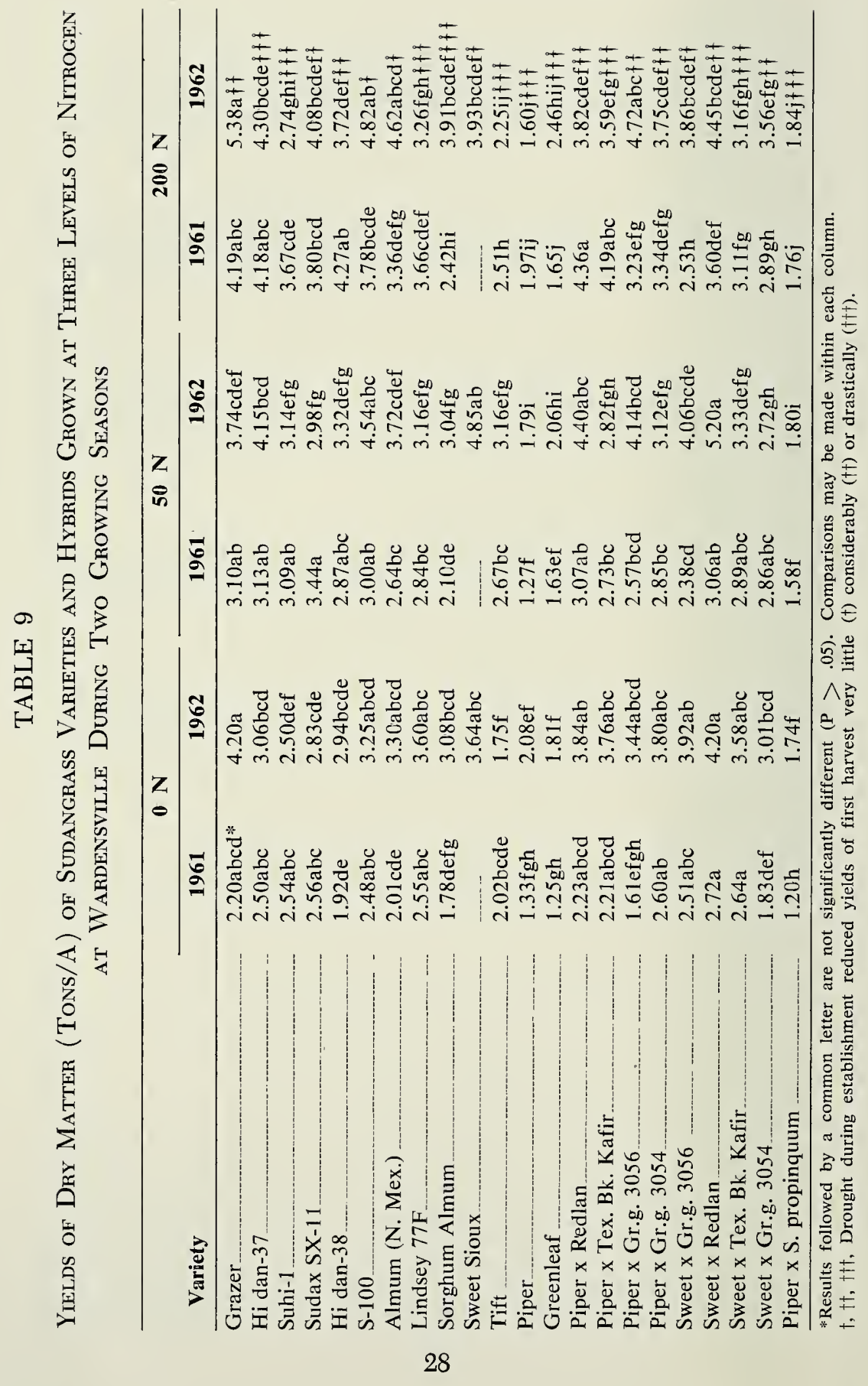


dry-matter yields increased with additional increments of nitrogen. An average yield increase was obtained of 19 per cent for 50 pounds per acre and 59 per cent for 200 pounds per acre of nitrogen over the yield of the unfertilized grass (Figure 4). However, the analysis of variancs for each year (three locations combined) indicated a significant varieiy $\mathrm{X}$ nitrogen interaction. Varieties and hybrids responded differently to the application of 50 pounds of nitrogen per acre. Certain varieties and hybrids produced more forage, whereas other varieties and hybrids produced an equal amount or less forage with the 50-pound-per-acre level of nitrogen fertilization than with no nitrogen (Tables $7,8,9$ ). On the other hand, large yield increases were usually obtained for all entries with the 200-pound increment of nitrogen. It was noted, however, at Wardensville in 1962 (Table 9) that stand establishment of several varieties was adversely affected with high rates of nitrogen fertilization. Piper was affected most severely in this respect. This apparently was an interaction between nitrogen fertilization and soil moisture, since it was very droughty following seeding. This effect was not noted with a moderate or high soil moisture content.

\section{PART II: Nutritive Value-Animal Trials}

Date of Cutting. The effect of stage of maturity and nitrogen fertilization on the feeding value of Piper Sudangrass for sheep was examined in 1960 and 1961. Stands established in Morgantown were treated in the first year with 500 pounds of 0-8.7-16.6 fertilizer per acre, followed by 100 pounds of nitrogen (as urea) per acre. In the second year, two levels of nitrogen were used, 100 pounds and 300 pounds per acre. Trial data for yield and growth stage are summarized in Table 10.

The Sudangrass was clipped daily and fed in the fresh, chopped form in a series of 7-day intake and digestibility trials. In 1960 three sheep were used per treatment, in 1961 six sheep. Fecal collections were made by harness (Figure 5) on three sheep. Ad libitum intake at the 15 per cent refusal level was determined for all animals.

The effects of date of cutting and nitrogen fertilization on digestibility, intake and a Nutritive Value Index (per cent digestible dry matter $X$ relative intake) are presented in Appendix Table 3. Some of the more significant effects of growth stage on the feeding value of Sudangrass are outlined in Figures 6-8. Figure 6 illustrates the relationship between cutting date and both digestibility of dry matter and $a d l i b$. intake in the first and second cuttings of the grass. The rate of decline in both factors was especially marked during the first three weeks of growth, or up to the stage of early bloom. Figure 7 indicates that there was a linear rela- 
DA - 0 Ibs N/A $\square$ - 50 lbs N/A $\square-200 \mathrm{lbs}$ N/A

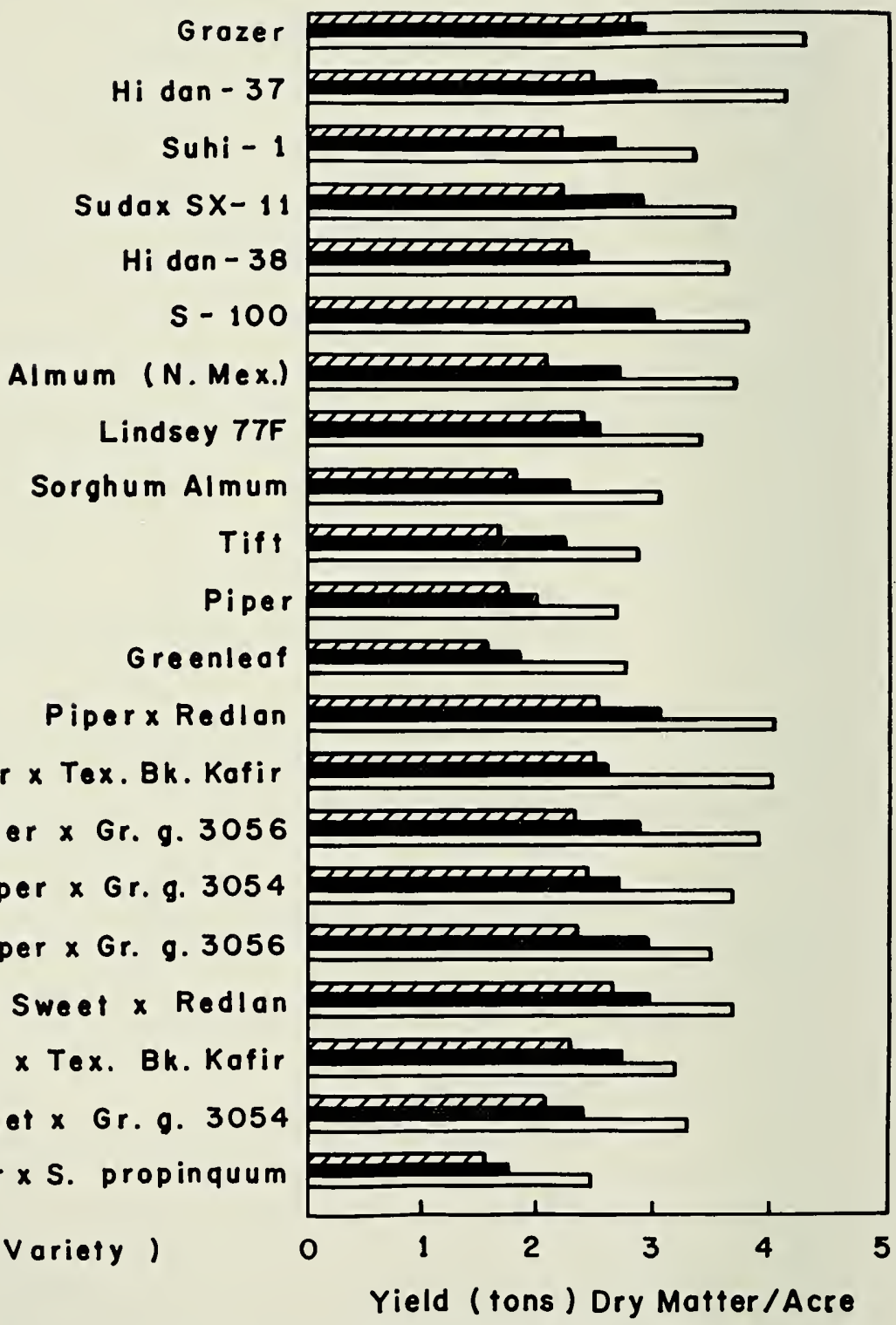

Figure 4. Yield of dry matter of Sudangrass varieties and hybrids grown at three levels of nitrogen fertilization (average of three locations for two seasons). 
TABLE 10

Effect of Stage of Maturity and Nitrogen Fertilization on DryMatter Yield (Tons/Acre) of Piper Sudangrass

\begin{tabular}{|c|c|c|c|c|c|}
\hline Trial Date & Treatment & $\begin{array}{l}\text { Stage of } \\
\text { Maturity }\end{array}$ & & $\begin{array}{c}\text { Height } \\
\text { of } \\
\text { Plant, } \\
\text { Inches }\end{array}$ & Yield \\
\hline $\begin{array}{l}6 / 25 / 60-7 / 2 / 60 \\
7 / 9 / 60-7 / 16 / 60 \\
7 / 23 / 60-7 / 30 / 60 \\
8 / 8 / 60-8 / 15 / 60 \\
8 / 8 / 60-8 / 15 / 60 \\
8 / 20 / 60-8 / 27 / 60\end{array}$ & 100 lbs. N. & $\begin{array}{l}\text { Vegetative } \\
\text { Heading } \\
\text { Bloom } \\
\text { Seed-forming } \\
\text { Vegetative } \\
\text { Heading }\end{array}$ & $\begin{array}{l}\text { First } \\
\text { cutting; }\end{array}$ & $\begin{array}{c}24 \\
46 \\
60-72 \\
60-72 \\
17-20 \\
50\end{array}$ & $\begin{array}{l}0.73 \\
1.25 \\
2.46 \\
2.36 \\
0.36 \\
1.66\end{array}$ \\
\hline $\begin{array}{l}7 / 10 / 61-7 / 16 / 61 \\
7 / 20 / 61-7 / 26 / 61 \\
7 / 31 / 61-8 / 6 / 61 \\
8 / 10 / 61-8 / 16 / 61 \\
8 / 23 / 61-8 / 29 / 61 \\
9 / 6 / 61-9 / 12 / 61 \\
7 / 31 / 61-8 / 6 / 61 \\
8 / 10 / 61-8 / 16 / 61 \\
8 / 23 / 61-8 / 29 / 61 \\
9 / 6 / 61-9 / 12 / 61\end{array}$ & 100 lbs. N. & $\begin{array}{l}\text { Vegetative } \\
\text { Boot } \\
\text { Early bloom } \\
\text { Full bloom } \\
\text { Seed-forming } \\
\text { Seed mature } \\
\text { Vegetative } \\
\text { Vegetative } \\
\text { Vegetative } \\
\text { Boot }\end{array}$ & $\begin{array}{l}\text { First } \\
\text { cutting }\end{array}$ & $\begin{array}{c}30-36 \\
60 \\
84-96 \\
84-96 \\
84-96 \\
84-96 \\
36 \\
42-48 \\
48-54 \\
60\end{array}$ & $\begin{array}{l}0.92 \\
1.61 \\
2.77 \\
2.96 \\
4.20 \\
4.52 \\
1.50 \\
1.45 \\
1.34 \\
1.44\end{array}$ \\
\hline $\begin{array}{l}7 / 10 / 61-7 / 16 / 61 \\
7 / 20 / 61-7 / 26 / 61 \\
7 / 31 / 61-8 / 6 / 61 \\
8 / 10 / 61-8 / 16 / 61 \\
8 / 23 / 61-8 / 29 / 61 \\
9 / 6 / 61-9 / 12 / 61 \\
7 / 31 / 61-8 / 6 / 61 \\
8 / 10 / 61-8 / 16 / 61 \\
8 / 23 / 61-8 / 29 / 61 \\
9 / 6 / 61-9 / 12 / 61\end{array}$ & 300 lbs. $\mathrm{N}$ & $\begin{array}{l}\text { Vegetative } \\
\text { Boot } \\
\text { Early bloom } \\
\text { Full bloom } \\
\text { Seed-forming } \\
\text { Seed mature } \\
\text { Vegetative } \\
\text { Vegetative } \\
\text { Boot } \\
\text { Heading }\end{array}$ & $\begin{array}{l}\text { First } \\
\text { cutting }\end{array}$ & $\begin{array}{c}30 \\
60 \\
84 \\
84-96 \\
84-96 \\
84-96 \\
36 \\
48-54 \\
60 \\
60-72\end{array}$ & $\begin{array}{l}0.60 \\
2.29 \\
1.90 \\
4.03 \\
5.00 \\
4.52 \\
1.45 \\
1.55 \\
2.21 \\
1.59\end{array}$ \\
\hline
\end{tabular}

tionship between date of cutting (calculated as days after July 1) and dry-matter digestibility, although there was variability between years. The rate of decrease of digestibility of dry matter over the entire first cutting was 0.20 percentage units per day. This is somewhat lower than the decline in dry-matter digestibility of perennial grasses observed at this Station (51) and in adjoining states $(17,34,56)$. Considering only the 1961 forages, individual regression equations for digestibility on date of cutting were as follows:

$$
\begin{array}{ccc}
300 \text { pounds } \mathrm{N} & \mathrm{Y}=80.35-0.277 \mathrm{X} & \begin{array}{c}
\mathrm{Y}=\text { digestion coefficient } \\
\text { of dry matter }
\end{array} \\
100 \text { pounds } \mathrm{N} & \mathrm{Y}=79.26-0.261 \mathrm{X} & \begin{array}{c}
\mathrm{X}=\text { number of days after } \\
\text { July } 1
\end{array}
\end{array}
$$




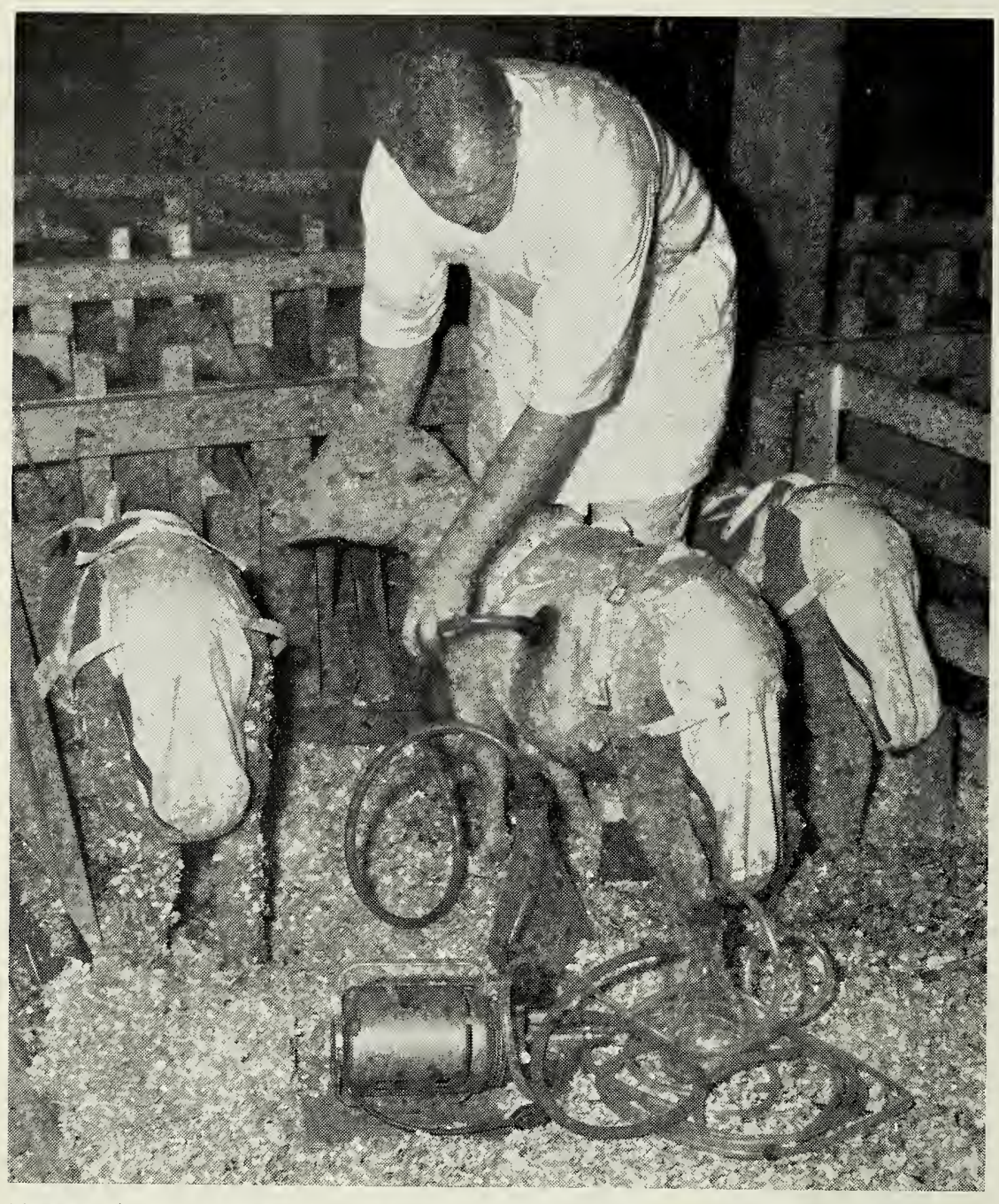

Figure 5. Digestibility and intake trials with sheep. Fistulated sheep are included as a source of rumen fluid for in vitro fermentation trials.

The rate of decrease in $a d$ lib. intake for both years was $0.30 \mathrm{~g} . / \mathrm{wt} . \mathrm{kg} .^{0.75}$ per day. The magnitude of the correlation coefficient $\left(-0.537^{* *}\right)$ and variability of the data would indicate, however, that date of cutting would be an imprecise means of predicting forage intake.

Figure 8 illustrates the pronounced effect of stage of maturity of Sudangrass on the protein content and on apparent protein digestibility by the animal. For example, the digestibility coefficient for protein in grass 


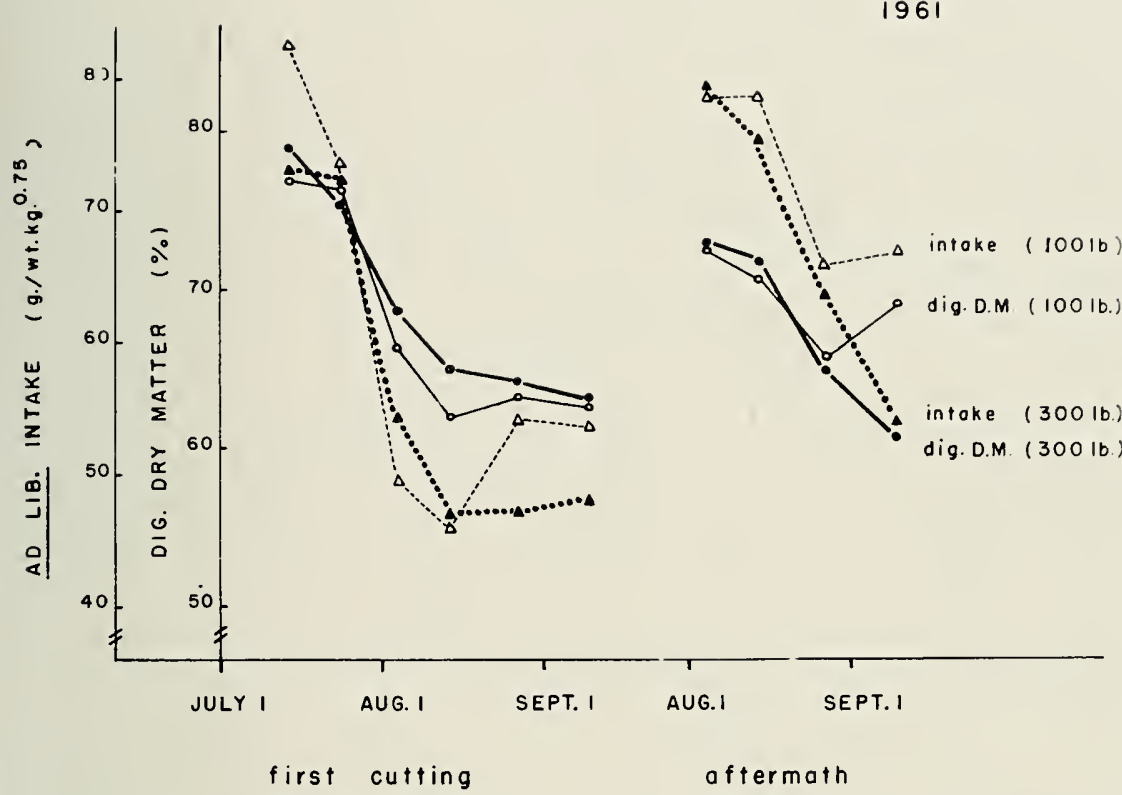

Figure 6. Effect of cutting date on digestibility and voluntary intake of Piper Sudangrass (fertilized at two levels of nitrogen) in 1961.

fertilized with 300 pounds nitrogen in 1961 dropped from 84.9 per cent in the second week of July to 39.4 per cent in the second week of Se?tember. Other workers $(30,65)$ have noted a high correlation between the protein content of perennial grasses and their apparent protein digestibility by cattle and sheep. This relationship is confirmed in the present study and may be expressed by the equation:

$$
\begin{aligned}
& \mathrm{Y}=34.80+2.93 \mathrm{X} \quad \mathrm{Y}=\text { digestion coefficient of protein } \\
& \mathrm{r}=+0.761^{*} \quad \mathrm{X}=\text { crude protein as per cent of dry } \\
& \text { matter }
\end{aligned}
$$

It may be noted, however, that the correlation between these two factors is not as high as has been reported in other studies with perennial forages.

The Significance of Intake. The relationship between the digestibility of dry matter and the level of intake of forages by ruminant animals is presently unresolved. British studies with cattle and sheep $(5,15)$ have indicated that there is a positive correlation between these two criteria. This would imply that the level of voluntary consumption of forages might consistently be predicted from a knowledge of the content of 


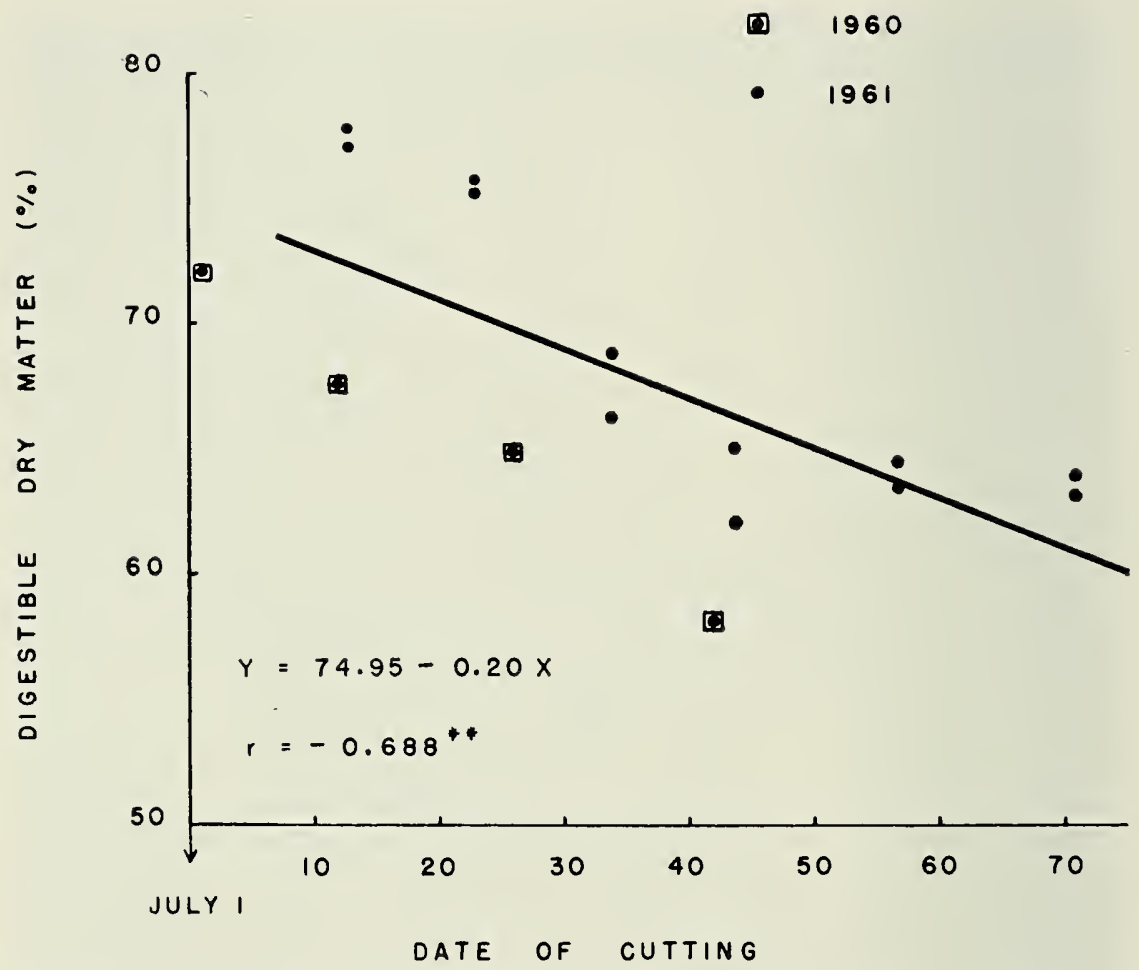

Figure 7. Regression of dry-matter digestibility on date of cutting in 1960 and 1961.

digestible energy. Intake trials at West Virginia (54) have shown that the relationship between intake and digestibility of nutrients may be markedly affected by such factors as species of forage and growth phase (i.e., first cutting vs. aftermath forages). The present study does, however, indicate a highly significant correlation $\left(+0.811^{*}\right)$ between ad lib. intake and per cent digestible dry matter for first-cutting Sudangrass samples in 1960 and 1961. The regression of intake on digestible dry matter is illustrated in Figure 9.

It has become abundantly clear in recent years that, in order to arrive at a meaningful estimate of forage nutritive value, it is necessary to take into account not only the digestible nutrient content of the forage, but the amount consumed by the animal. This may be expressed in different ways; Blaxter (5) has used intake of digestible calories per unit of metabolic size; intake of digestible organic matter has been proposed by New Zealand workers; Crampton (20) has suggested the use of a 


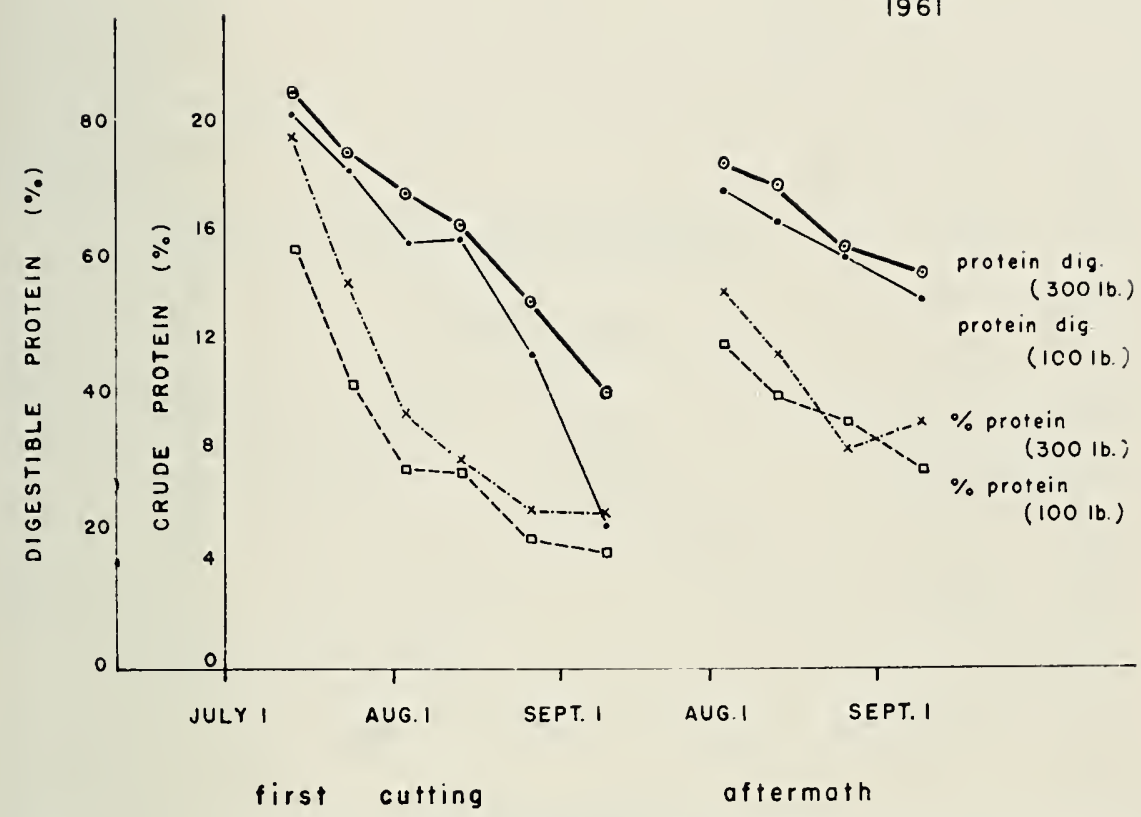

Figure 8. Relationship between cutting date and protein content and protein digestibility of Piper Sudangrass in 1961.

Nutritive Value Index (N.V.I.), which is essentially intake of digestible energy related to a standard forage.

Figure 10 illustrates the effect of stage of maturity of Sudangrass on the intake of digestible dry matter by sheep. An attempt has been made to partition this factor further into maintenance and productive functions by relating the total digestible dry-matter intake values to a calculated maintenance requirement for stall-fed sheep, with the realization that this is not a fixed quantity. The fraction to the right of the vertical division therefore represents that amount of digestible dry matter which is potentially available for the production of meat and wool. The very marked effect of stage of maturity or cutting date on both N.V.I. values and the "productive index" may be noted. During the vegetative and boot stage of growth in the first-cutting Sudangrass would support a satisfactory level of animal production (more than twice maintenance). After early bloom very little of the consumed forage would be available above the sheep's requirement for maintenance. This was substantiated by observed weight changes in the sheep on trial. Over the last six weeks of feeding first-cutting grass in 1961 there was no significant weight gain in the experimental animals. 


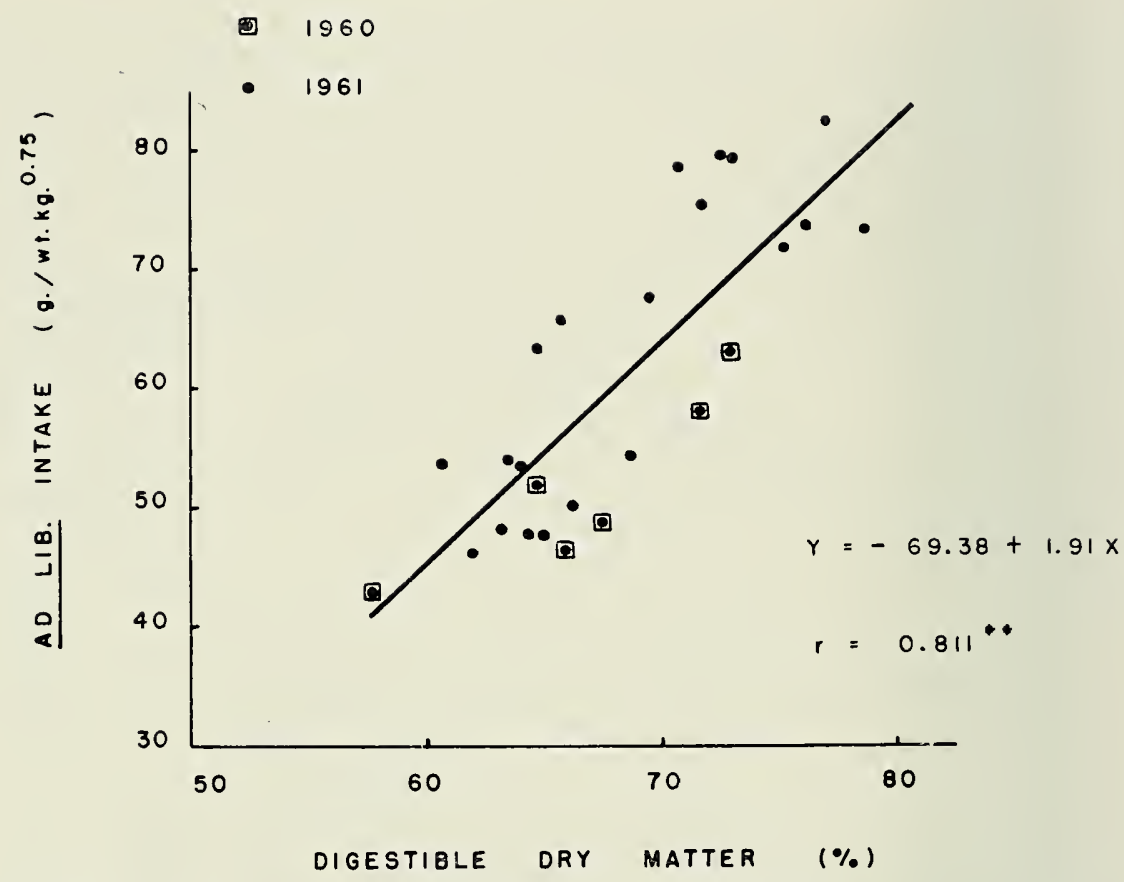

Figure 9. Regression of voluntary intake on the digestibility of dry matter of Piper Sudangrass by sheep.

The trends noted in the aftermath forages were similar to those obtained for the first-cutting forages. Intake of aftermath cuttings was generally high; the rather lower N.V.I. values obtained in relation to comparable growth stages in the first cutting reflect the fact that the dry-matter digestibility of aftermath forages tends to be significantly lower than that of first-cutting grasses $(49,50)$.

Yield in Relation to Nutritive Values. It may be concluded that, in terms of both content of digestible nutrients and of dry-matter intake, there are marked advantages to the early harvesting of Sudangrass. It has also been pointed out by Blaxter (6) that "the optimal time of cutting depends on the type of animal husbandry envisaged." In other words, if the primary purpose of producing a forage crop is to maintain a larger number of animals over an extended period of time without gaining weight (as in wintering beef cattle or sheep), it might be advantageous to harvest late and to compensate for the reduced unit nutritive value of the forage by the increase in yield obtained. The number of aftermath cuttings likely to be obtained, and their nutritive value, should also be considered in arriving at an optimal cutting date. 

1961
100 Ib. N

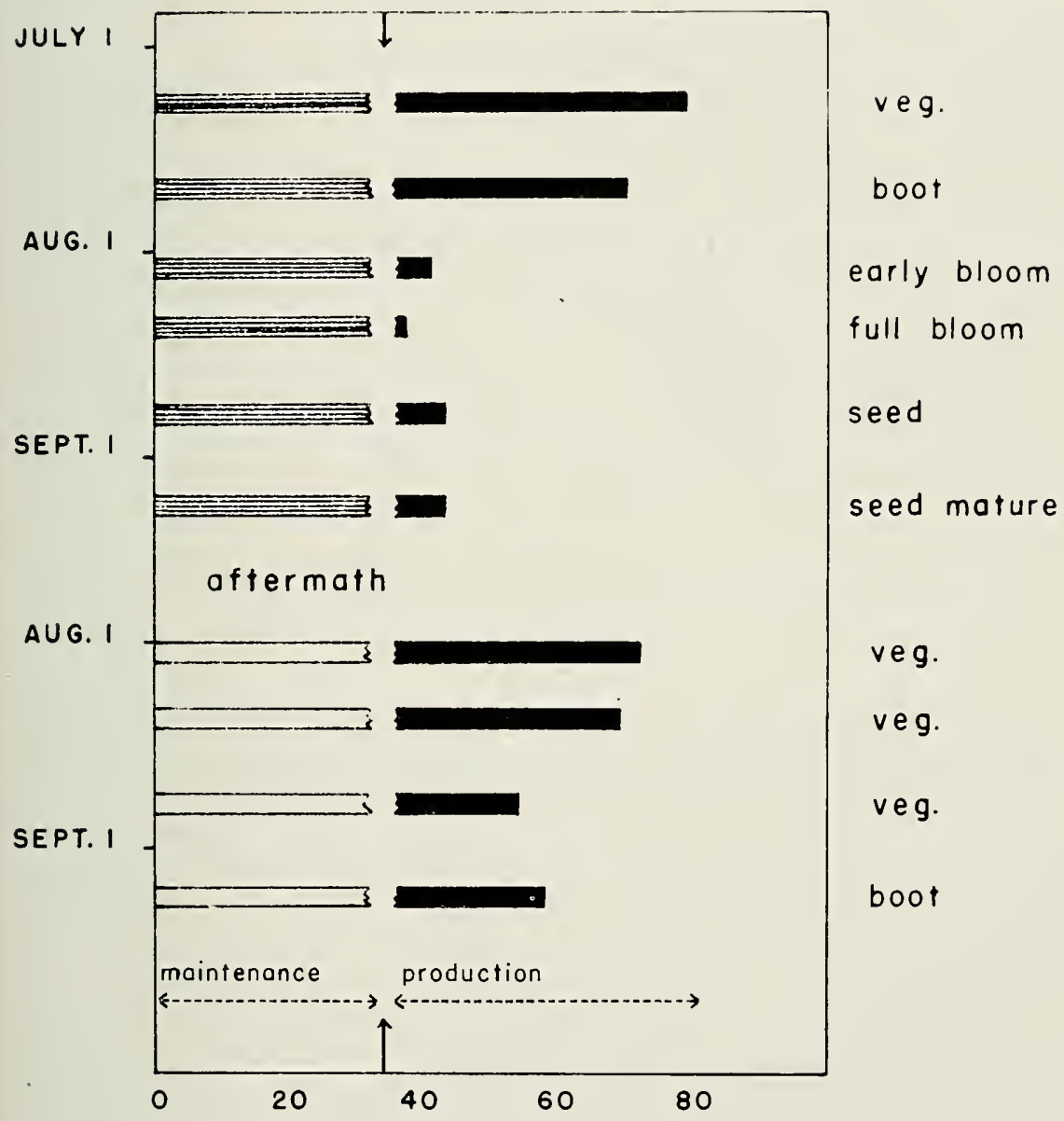

INTAKE OF DIG. DRY MATTER (N.V.I.)

Figure 10. Relationship between stage of maturity and the productive value of Sudangrass.

In the present study an average yield of digestible dry matter for Sudangrass harvested at the boot stage (July 20-July 26) in 1961 was 1.48 tons per acre. When harvested at the fully mature seeded stage (September 6-12) the yield was 2.87 tons per acre. The earlier cutting date, however, permitted the production of an aftermath (September 
6-12) which yielded 0.98 tons of digestible dry matter per acre. In aggregate, the early harvest gave a total season productivity of 2.46 tons of digestible dry matter per acre, of high productive capacity, as compared to 2.87 tons per acre for a late harvest, this forage allowing for little more than maintenance levels of production.

\section{PART III: Nutritive Value-Laboratory}

The conduct of animal trials to establish the feeding value of forages is time-consuming and expensive. Many workers have attempted to derive relationships for the prediction of nutritive criteria either from the chemical composition of the forage or from its fermentation properties in some form of artificial rumen $(4,32)$.

Chemical Composition. Table 11 summarizes analytical data for the 1961 Sudangrass samples. Dry matter and crude protein were determined by standard A.O.A.C. procedures. Cellulose was determined by the method of Crampton and Maynard (19). Cell-wall components, aciddetergent fiber and lignin were estimated by detergent extraction procedures developed by Van Soest $(69,70)$. Seasonal trends in these constituents are plotted in Figure 11. The changes with growth stage of the plant are of the same order as have been observed for perennial grasses (47).

In Figure 12 regressions of digestible dry matter upon chemical components are plotted. Individual regression equations, together with simple or multiple correlation coefficients, are given in Table 12. It may be seen that there is a direct linear relationship between digestibility of dry matter and the plant content of crude protein, acid-detergent fiber, cell-wall components and lignin. A curvilinear function was found to estimate dry-matter digestibility from dry-matter content of the fresh grass better than a rectilinear function.

These regressions indicate that the dry-matter digestibility of Sudangrass may be predicted with reasonable accuracy from any one of several plant constituents. The possibility of improving the accuracy of prediction by using a combination of components (crude protein, acid-detergent fiber, cell-wall components and lignin) was tested in a multiple regression analysis.

The regression obtained was:

$$
\begin{array}{ll}
\mathrm{Y}=108.56+0.19 \mathrm{X}_{1}+0.48 \mathrm{X}_{2}-0.88 \mathrm{X}_{3}-1.51 \mathrm{X}_{4} \\
\mathrm{R}=+0.889^{* * *} & \mathrm{Y}=\text { digestion coefficient of dry matter } \\
\mathrm{X}_{1}=\text { per cent crude protein } \\
\mathrm{X}_{2}=\text { per cent acid-detergent fiber } \\
\mathrm{X}_{3}=\text { per cent cell-wall components } \\
\mathrm{X}_{4}=\text { per cent lignin }
\end{array}
$$




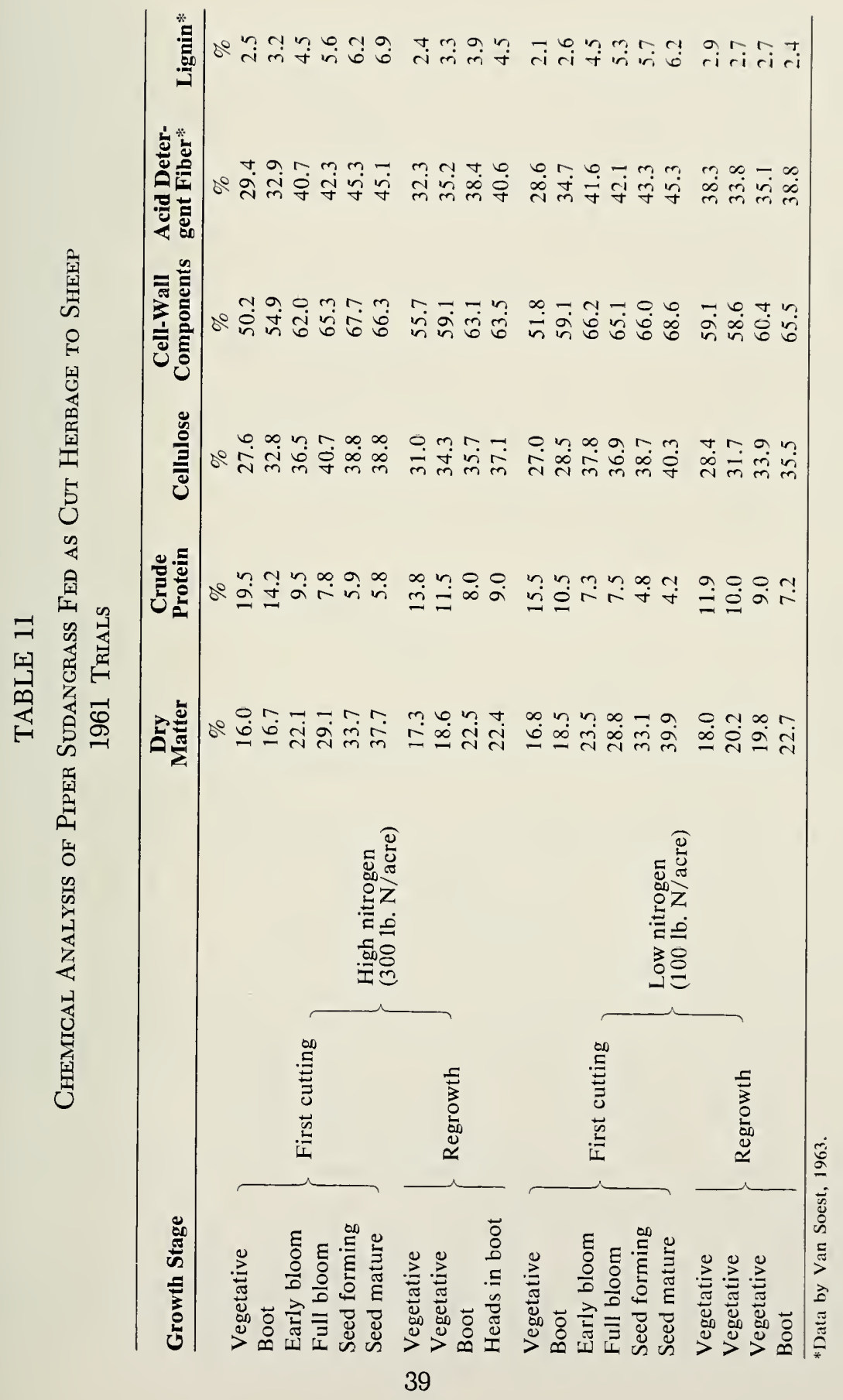




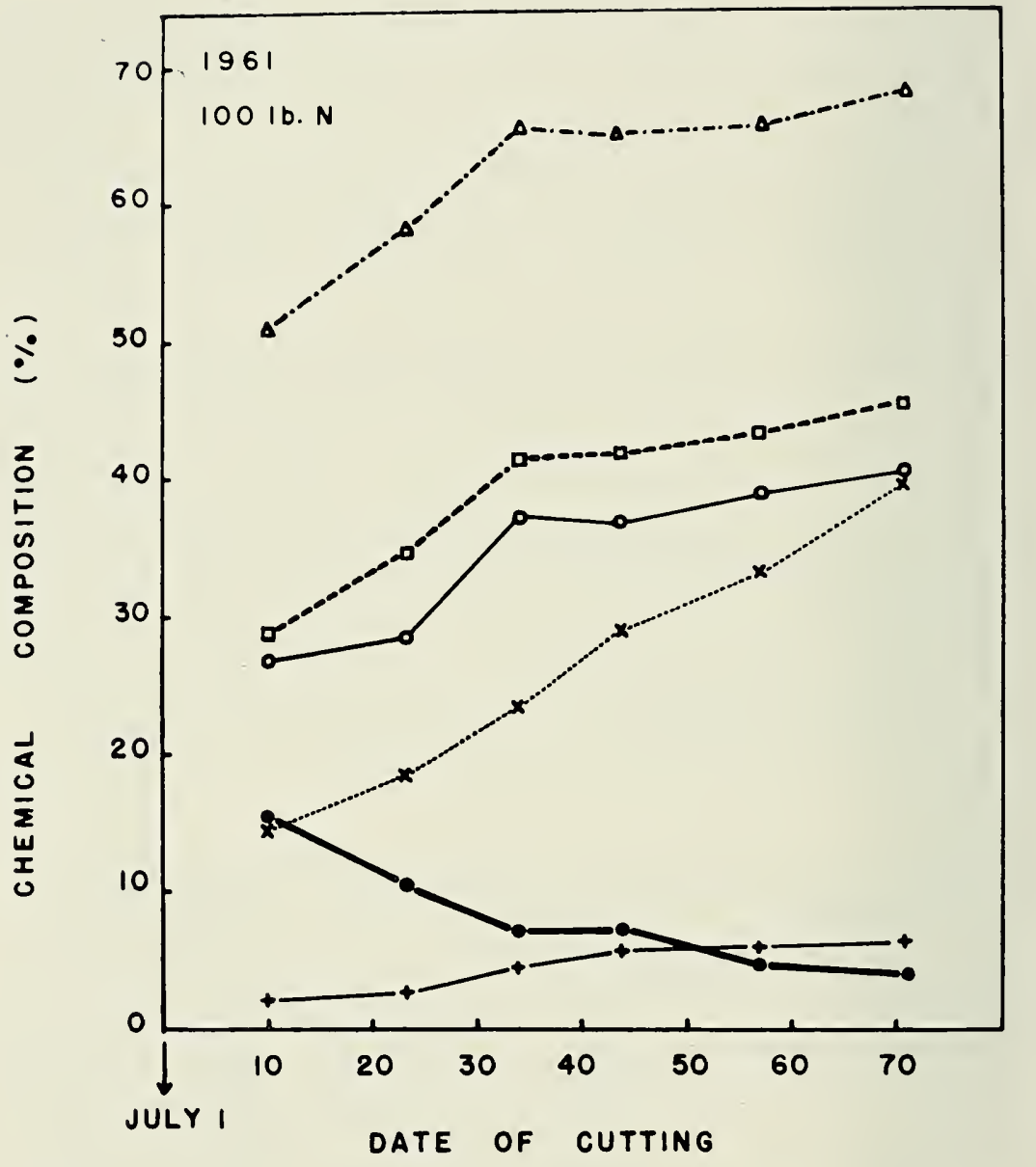

x.......... dry motter

$\longrightarrow$ crude protein

C cellulose
$\Delta-\cdots \cdot \Delta$ cell wall components o-.---o ocid detergent fiber $+\ldots+$ lignin

Figure 11. Changes in plant constituents with advancing maturity (days after July 1) of Sudangrass.

The multiple correlation coefficient is higher than that obtained between dry-matter digestibility and the individual chemical fractions, but the difference would not appear to be of practical significance. 


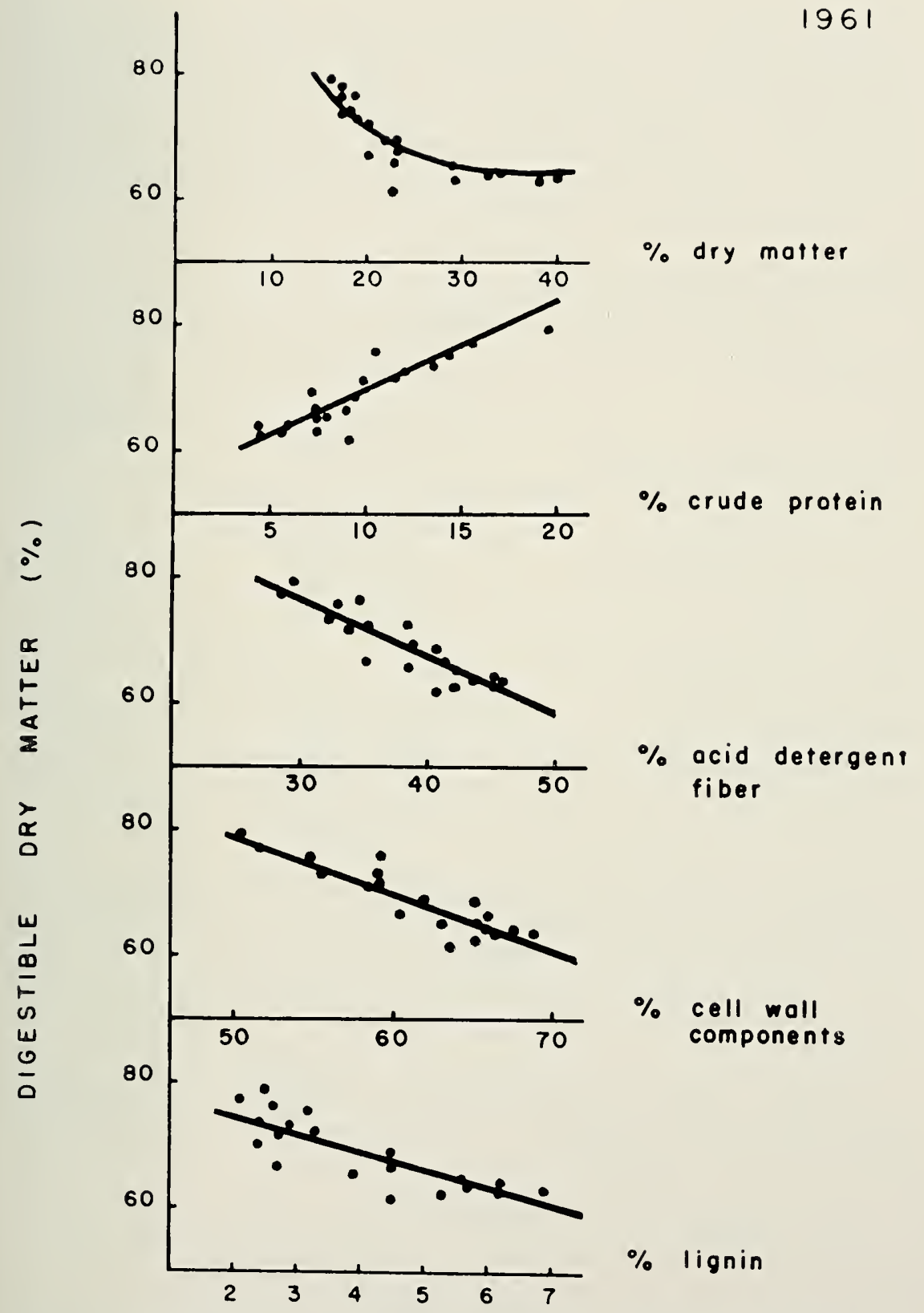

Figure 12. Relationship between individual chemical components of Sudangrass and digestibility of dry matter by sheep. 
In a similar fashion, regressions of ad lib. intake upon dry-matter content, crude protein, acid-detergent fiber, cell-wall components and lignin are plotted in Figure 13. The relationship between intake and percentage of dry matter in the green plant was found to be a curvilinear function; the remainder of the regressions were rectilinear. Individual regression equations and correlation coefficients are given in Table 12.

\section{TABLE 12}

Regression of Digestibility of Dry Matter and of Ad Lib. Intake (Y) Upon Chemical Composition (X) of Sudangrass

\begin{tabular}{|c|c|c|}
\hline & Regression equation & $\begin{array}{l}\text { Correlation } \\
\text { coefficient } \\
\text { (r or } \mathbf{R})\end{array}$ \\
\hline \multicolumn{3}{|l|}{$\mathrm{Y}=$ digestible dry matter $(\%)$} \\
\hline$X=$ dry matter $(\%)$ & $Y=121.30-3.72 X+0.06 X^{2}$ & $0.886 * *$ \\
\hline$=$ crude protein $(\%)$ & $Y=56.94+1.22 X$ & $0.856^{* *}$ \\
\hline$=$ acid detergent fiber $(\%)$ & $Y=103.05-0.90 X$ & $-0.852 * \%$ \\
\hline$=$ cell-wall components $(\%)$ & $Y=124.37-0.91 X$ & $-0.872 * *$ \\
\hline$=$ lignin $(\%)$ & $Y=79.83-2.78 X$ & $-0.777 *$ \\
\hline \multicolumn{3}{|l|}{$\mathrm{Y}=$ ad lib. intake (g./wt.kg. $\left.{ }^{0.75}\right)$} \\
\hline $\mathrm{X}=$ dry matter $(\%)$ & $Y=177.14-7.86 X+0.12 X^{2}$ & $0.887 * *$ \\
\hline$=$ crude protein $(\%)$ & $Y=39.59+2.46 X$ & $0.738 * *$ \\
\hline$=$ acid detergent fiber $(\%)$ & $Y=146.45-2.18 X$ & $-0.876 * *$ \\
\hline$=$ cell-wall components $(\%)$ & $Y=186.74-2.01 X$ & $-0.823 * *$ \\
\hline$=$ lignin $(\%)$ & $Y=93.45-7.51 X$ & $-0.893 * *$ \\
\hline
\end{tabular}

Again, all correlation coefficients were highly significant $(\mathrm{P}<.01)$. In comparing relationships obtained between the various chemical fractions and either digestibility of dry matter or ad lib. intake, it may be noted that the correlation of crude protein with intake was lower than with dry-matter digestibility, and that the reverse was true for the lignin fraction.

A multiple regression of $a d$ lib. intake on percentage of crude protein, acid-detergent fiber, cell-wall components and lignin was run and the following equation obtained:

$$
\begin{array}{ll}
\mathrm{Y}=323.49-3.30 \mathrm{X}_{1}+1.78 \mathrm{X}_{2}-4.35 \mathrm{X}_{3}-7.31 \mathrm{X}_{4} \\
\left.\mathrm{Y}=+0.939^{* *}=a d \text { lib. intake (g./wt.kg. }{ }^{0.75}\right) \\
\mathrm{X}_{1}=\text { per cent crude protein } \\
\mathrm{X}_{2}=\text { per cent acid-detergent fiber } \\
\mathrm{X}_{3}=\text { per cent cell-wall components } \\
\mathrm{X}_{4}=\text { per cent lignin }
\end{array}
$$




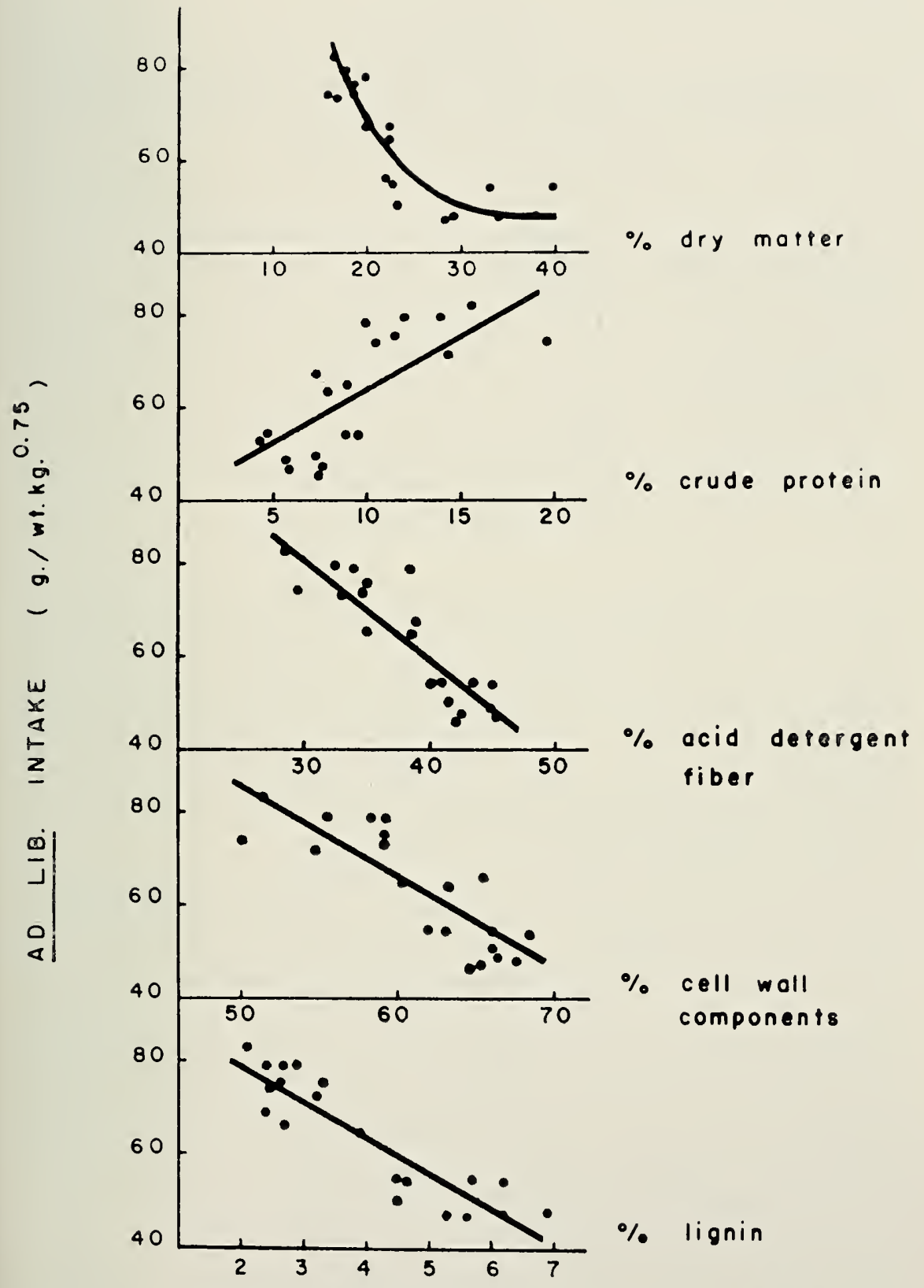

Figure 13. Relationship between individual chemical components of Sudangrass and level of voluntary intake by sheep. 
Effect of Plant Constituents on Regression Equations for the Prediction of Dry-Matter Digestibility, $A d$ Lib. Intake and a Nutritive Value Index

\begin{tabular}{|c|c|c|c|c|}
\hline \multirow[b]{2}{*}{$\begin{array}{l}\text { Components contained } \\
\text { in regression equation }\end{array}$} & \multirow{2}{*}{$\begin{array}{l}\text { Component } \\
\text { added to } \\
\text { regression } \\
\text { equation }\end{array}$} & \multicolumn{3}{|c|}{ F-ratio } \\
\hline & & $\underset{(\%)}{\text { Dry matter dig. }}$ & $\begin{array}{c}\text { Intake } \\
\text { (g./wt.kg. }{ }^{0.75} \text { ) }\end{array}$ & N.V.I. \\
\hline $\begin{array}{l}\text { Fiber, cell-wall } \\
\text { constituents, lignin }\end{array}$ & Protein & 0.06 & $5.95 *$ & 2.84 \\
\hline $\begin{array}{l}\text { Protein, cell-wall } \\
\text { constituents, lignin. }\end{array}$ & Fiber & 0.37 & 1.63 & 1.52 \\
\hline Protein, fiber, lignin & $\begin{array}{l}\text { Cell-wall } \\
\text { constituents }\end{array}$ & 0.91 & $7.12 *$ & $5.98 *$ \\
\hline $\begin{array}{l}\text { Protein, fiber, cell- } \\
\text { wall constituents }\end{array}$ & Lignin & 1.53 & $11.47 * *$ & $8.43 * *$ \\
\hline
\end{tabular}

A comparison of the $\mathrm{F}$ ratios obtained in an analysis of variance showed that, of the chemical components found to influence intake, the percentage of lignin in the plant was of greatest significance (Table 13). A multiple correlation coefficient of +0.939 was higher than coefficients obtained between intake and any individual chemical fraction. The magnitude of the $R$ value indicates that use of a combination of chemical constitutents in regression would predict animal ad lib. intake with very acceptable accuracy.

In Vitro Data. The artificial rumen has been used with considerable success in the prediction of the energy or dry-matter digestibility of forages $(32,54)$. Attempts to relate the level of forage intake to the rate of fermentation of fiber components in an in vitro system have, in general, indicated a lesser accuracy of prediction (54). This might be expected in view of the possible effects of such factors as forage palatability and the high variability of animal response in intake trials. Canadian workers (22) have, however, obtained significant positive correlations between the intake of digestible energy of hays by sheep and the rate of digestion of cellulose as determined at an early (6-12-hr.) period of fermentation in an in vitro system.

Using the Sudangrass samples harvested in 1960 and 1961, digestibility of dry matter by the animal was plotted against digestibility of cellulose determined at $36 \mathrm{hrs}$. in vitro. The regression was linear (Figure 14). The magnitude of the correlation coefficient $\left(+0.817^{* *}\right)$ indicated, however, that there would in this instance be no advantage to the use 
of in vitro digestibility data over individual chemical fractions for the prediction of the animal digestibility coefficient.

Since more intake data were available from feeding trials carried out in 1961, only these samples were used in a study of the relationship

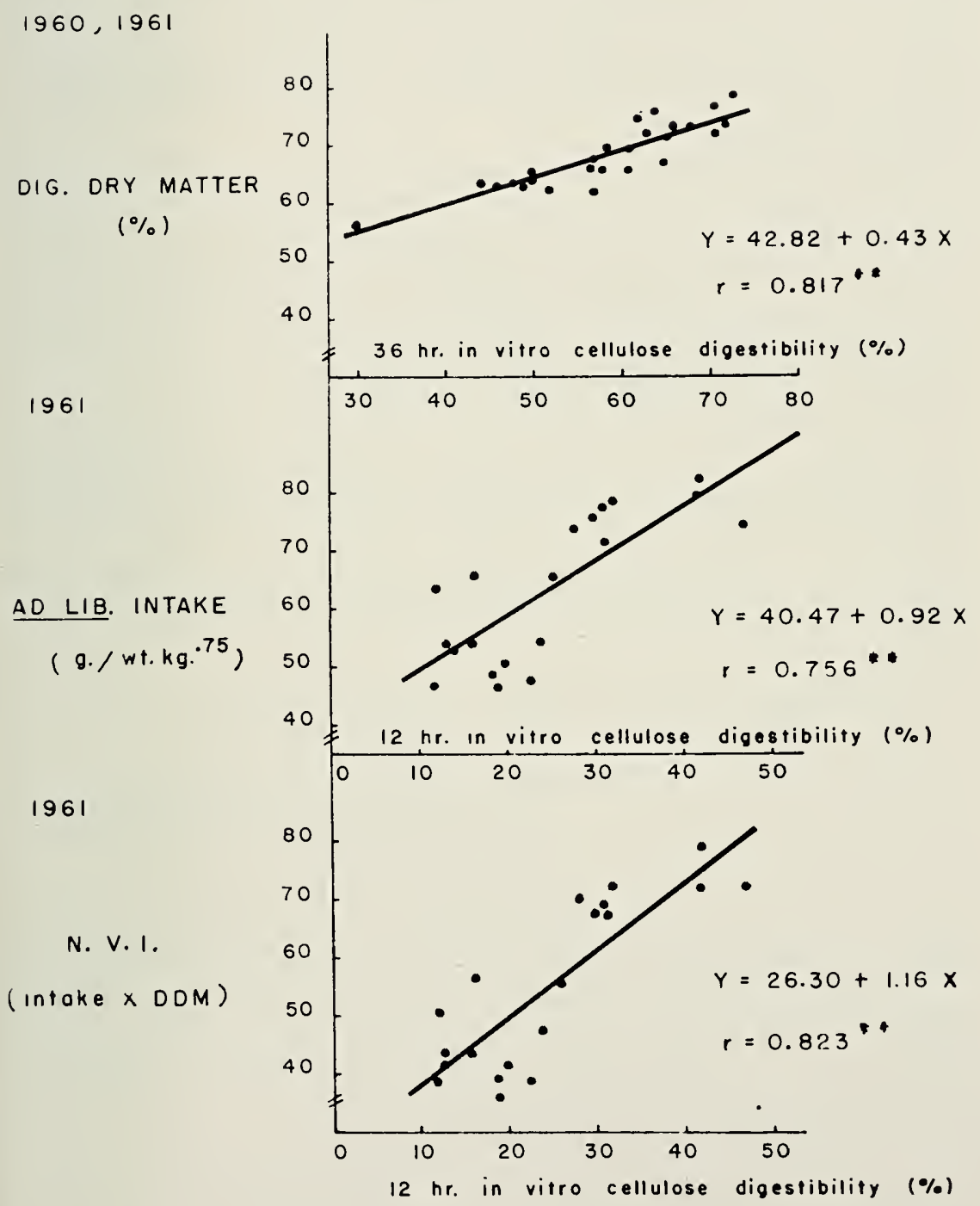

Figure 14. Regression of rates of in vitro cellulose digestion on drymatter digestibility, voluntary intake and a calculated Nutritive Value Index. 
between ad lib. intake and the rate of digestion of forage samples in vitro. Two techniques were used in laboratory rate studies: (1) in vitro cellulose digestion was determined by established procedures (33) at intervals of $0,4,8,12,24$ and 36 hrs., (2) gas production was measured continuously in a modified in vitro system $(51,53)$ over a $36-\mathrm{hr}$. period. Previous work had shown that rates of fermentation as measured by these two methods were highly correlated. Data for in vitro cellulose digestion and in vitro gas production at 12, 24 and 36 hrs. are given in Appendix Table 4.

The regression of ad lib. intake on 12-hr. in vitro cellulose digestibility is given in Figure 14. There was a linear relationship between these two factors, but it may be seen that the correlation coefficient $\left(+0.756^{* *}\right)$ was lower than that obtained between digestible dry matter and 36-hr. in vitro cellulose digestibility. It was also somewhat lower than correlation coefficients observed between ad lib. intake and the majority of the individual chemical constitutents of the grass.

Finally, Figure 14 illustrates the regression of a calculated Nutritive Value Index on 12-hr. in vitro cellulose digestibility. The relationship was linear and there was a highly significant positive correlation $\left(+0.823^{* *}\right)$ between these two factors. This may be compared to the results of a multiple regression analysis of N.V.I. on the content of crude protein, acid-detergent fiber, cell-wall components and lignin in the 1961 Sudangrass samples:

$$
\begin{array}{ll}
\mathrm{Y}=309.99-2.57 \mathrm{X}_{1}+1.94 \mathrm{X}_{2}-4.49 \mathrm{X}_{3}-7.06 \mathrm{X}_{4} \\
\mathrm{R}=+0.942^{*} & \mathrm{Y}=\text { Nutritive Value Index } \\
& \mathrm{X}_{1}=\text { per cent crude protein } \\
& \mathrm{X}_{2}=\text { per cent acid-detergent fiber } \\
& \mathrm{X}_{3}=\text { per cent cell-wall components } \\
& \mathrm{X}_{4}=\text { per cent lignin }
\end{array}
$$

The results indicate that while the accuracy of prediction of intake from 12-hr. in vitro cellulose or gas production data is comparable to that obtained with individual chemical components of the forage, it is not as good as that obtained when a combination of plant constituents is used. 


\section{Bibliography}

1. Ahlgren, H. L., G. M. Briggs and L. F. Graber. Supplementary pastures and hays. Wisc. Agr. Expt. Sta. Ext. Circ. 315. 1941.

2. Arny, A. C., R. Crim and R. O. Bridgford. Supplementary and emergency crops for Minnesota. Minn. Agr. Expt. Sta. Bull. 390. 1946.

3. Baker, T. A., C. R. Richards, G. F. W. Haenlein and H. G. Weaver. Factors affecting the consumption of Sudangrass by dairy cows. J. Dairy Sci., 43: 958-65. 1960.

4. Barnett, A. J. G. and R. L. Reid. Reactions in the Rumen. Ed. Arnold, London. 1961.

5. Blaxter, K. L., F. W. Wainman and R. S. Wilson. The regulation of food intake by sheep. An. Prod., 3: 51-61. 1961.

6. Blaxter, K. L. and R. S. Wilson. The assessment of a crop husbandry technique in terms of animal production. An. Prod., 5: 27-42. 1963.

7. Boyd, F. T., O. S. Aamodt, G. Bohstedt and E. Truog. Sudangrass management for control of cyanide poisoning. J. Am. Soc. Agron., 30: 569-82. 1938.

8. Brown, B. A. Summer annuals for hay in Connecticut. Storrs Agr. Expt. Sta. Bull. 120. 1924.

9. Browning, C. B., W. C. Cowsert, W. D. Craft and J. T. Miles. Permanent vs. temporary summer pastures for milk production. Miss. Agr. Expt. Sta. Bull. 624. 1961.

10. Broyles, K. R. and H. A. Fribourg. Nitrogen fertilization and cutting management of Sudangrasses and millets. Agron. J., 51: 277-79. 1959.

11. Brunnich, I. C. Hydrocyanic acid in fodder plants. J. Chem. Soc., 28: 788-96. 1903.

12. Burger, A. W., J. A. Jackobs and C. N. Hittle. Yield of Sudangrass varieties as affected by time and frequency of cutting. Agron. J., 50: 37-39. 1958.

13. Burger, A. W. and W. F. Campbell. Effect of rates and methods of seeding on the original stand, tillering, stem diameter, leaf-stem ratio and yield of Sudangrass. Agron. J., 55: 289-91. 1961.

14. Burns, J. C. and W. F. Wedin. Yield and chemical composition of Sudangrass and forage sorghum under three systems of summer management for late fall in situ utilization. Agron. J., 56: 457-60. 1964.

15. Campling, R. C. Factors affecting the voluntary intake of grass. Proc. Nutr. Soc., 23: 80-88. 1964.

16. Carter, J. F., D. W. Bolin and E. Duane. The evaluation of forages by the "agronomic difference" method and the chromogen-chromic oxide indicator technique. N. Dakota Agr. Expt. Sta. Tech. Bull. 426. 1960.

17. Conrad, H. R., J. W. Hibbs, A. D. Pratt and R. R. Davis. Relationships between forage growth stage, digestibility, nutrient intake and milk production in dairy cows. Ohio Agr. Bull. 914.1962.

18. Cragmiles, J. P., D. M. Baird and M. E. McCullough. Quality evaluation of Sundangrass and millet forage. Georgia Agr. Expt. Sta. Mimeo. Ser. N.S. 48. 1958.

19. Crampton, E. W. and L. A. Maynard. The relation of cellulose and lignin content to the nutritive value of animal feeds. J. Nutr., 15: 383-88. 1938. 
20. Crampton, E. W., E. Donefer and L. E. Lloyd. A Nutritive Value Index for forages. J. Animal Sci., 19: 538-44. 1960.

21. Dawson, J. R., R. R. Graves and A. G. Van Horn. Sudangrass as hay, silage and pasture for dairy cattle. U.S.D.A. Tech. Bull. No. 352. 1933.

22. Donefer, E., E. W. Crampton and L. E. Lloyd. Prediction of the Nutritive Value Index of a forage from in vitro rumen fermentation data. J. Animal Sci., 19: 545-52. 1960.

23. Dorrance, A. B. Sudan is a valuable pasture crop in Michigan. Mich. Agr. Expt. Sta. Quart. Bull. 13. 1931.

24. Dowell, C. F. A study of cyanogenesis in Sorghum vulgare. Okla. Agr. Expt. Sta. Tech. Bull. 122. 1919.

25. Franzke, C. J., L. F. Puhr and A. N. Hume. A study of sorghum with reference to the content of HCN. S. Dakota Agr. Expt. Sta. Tech. Bull. 1. 1939.

26. Gaessler, W. G. and A. C. McCandlish. Composition and digestibility of Sudangrass hay. Iowa Agr. Expt. Sta. Bull. 46. 1918.

27. Gangstad, E. O. Composition, yield and grazing studies of Sudan and related sorghums. Hoblitzelle Agr. Lab. Texas Research Foundation Bull. 7. 1959.

28. Hawkins, G. E., L. A. Smith and W. B. Kelley. A comparison of Starr millet, sweet Sudangrass, and Johnsongrass as dairy forages. Ala. Agr. Expt. Sta. Leaflet 60. 1958.

29. Hogg, P. G. and H. L. Ahlgren. A rapid method of determination of HCN content of single plants of Sudangrass. J. Am. Soc. Agron., 34: 199-200. 1942.

30. Holter, J. A. and J. T. Reid. Relationship between concentrations of crude protein and apparently digestible protein in forages. J. Animal Sci., 18: 1339. 1959.

31. Hughes, H. D. and F. S. Wilkins. Sudan grass. Iowa Agr. Expt. Sta. Bull. 233. 1926.

32. Johnson, R. R. Symposium on microbial digestion in ruminants: in vitro rumen fermentation techniques. J. Animal Sci., 22: 792-800. 1963.

33. Jung, G. A., B. Lilly, S. C. Shih and R. L. Reid. Studies with Sudangrass I. Effect of growth stage and level of nitrogen fertilizer upon yield of dry matter; estimated digestibility of energy, dry matter and protein; amino acid composition; and prussic acid potential. Agron. J., 56: 533-37. 1964.

34. Kane, E. A. and L. A. Moore. Digestibility of Beltsville first-cut forages affected by date of harvest. J. Dairy Sci., 42: 936. 1959.

35. Kiesselbach, T. A. and A. Anderson. Annual forage crops. Nebr. Agr. Expt. Sta. Bull. 206. 1925.

36. Krasteva, E. Studies on the hydrocyanogen content of green, dried and ensiled sugar sorghum, Sorghum vulgare var. technicum, and Sudangrass. Nauc. Trudove, viss. selskostop. Inst. "Georgi Dimitrov," Bulgaria (Zootehn. Fak.) 13: 123-34. 1963.

37. Lindsey, J. B., C. L. Beals and P. H. Smith. Digestion experiments with sheep. Mass. Agr. Expt. Sta. Bull. 181: 241. 1917.

38. Mays, D. A. and J. B. Washko. Cutting and grazing management for Sudangrass and pearl millet. Penna. Agr. Expt. Sta. Bull. 682. 1961.

39. Miller, R. W., D. R. Waldo, M. Okamoto, R. W. Hemken, J. H. Vandersall and N. A. Clark. Feeding of potassium bicarbonate or magnesium carbonate to cows grazed on Sudangrass or pearl millet. J. Dairy Sci., 46: 621-26. 1963. 
40. Miller, W. J., H. L. Dalton and J. K. Miller. Sudangrass silage at two stages of maturity versus rye grass and crimson clover with two filling procedures. J. Dairy Sci., 44: 1921-27. 1961.

41. Nelson, C. E. Hydrocyanic acid content of certain sorghums under irrigation as affected by nitrogen fertilizer and soil moisture stress. Agron. J., 45: 615-18. 1953.

42. Newlander, J. A. The digestibility of artificially dried Sudangrass. Vt. Agr. Expt. Sta. Bull. 386. 1935.

43. Odland, T. E., T. R. Cox and C. H. Moran. Adaptation of various crops for supplementary pasture. J. Am. Soc. Agron., 34: 229-37. 1942.

44. Olson, J. M. and J. A. Evans. Ten years of experimental results on cultivated pastures. S. Dakota Agr. Expt. Sta. Bull. 324. 1938.

45. Patel, C. J. and M. J. Wright. The effect of certain nutrients upon the hydrocyanic acid content of Sudangrass grown in nutrient solution. Agron J., 50: 645-47. 1958.

46. Pfander, W. H., D. Roberts, J. E. Comfort and J. G. W. Jones. Digestibility of wheat, Sudangrass, and drouth corn silages by wethers and steers. Mo. Agr. Expt. Sta. Bull. 628. 1957.

47. Phillips, T. G., J. T. Sullivan, M. E. Loughlin and V. G. Sprague. Chemical composition of some forage grasses. I. Changes with plant maturity. Agron. J., 46: 361-69. 1954.

48. Piper, C. V. Sudangrass, a new drought-resistant hay plant. Circ. Bur. Plant Ind., U.S.D.A., 125. 1913.

49. Reid, J. T., W. K. Kennedy, K. L. Turk, S. T. Slack, G. W. Trimberger and R. P. Murphy. Symposium on forage evaluation. I. What is forage quality from the animal standpoint? Agron. J., 51: 213-16. 1959.

50. ㄴ. Effect of growth stage, chemical composition, and physical properties upon the nutritive value of forages. J. Dairy Sci., 42: 567-70. 1959.

51. Reid, R. L. Investigation of plant species and maturity stage on forage nutritive value as determined by in vitro digestion techniques. Final Report, U.S.D.A. Contract No. 12-14-100-4524 (34). 1962.

52. Reid, R. L., G. A. Jung and S. Murray. The measurement of nutritive quality in a bluegrass pasture using in vivo and in vitro techniques. J. Animal Sci., 23: $700-10.1964$.

53. Reid, R. L., B. Clark and G. A. Jung. Studies with Sudangrass. II. Nutritive evaluation by in vivo and in vitro methods. Agron. J., 56: 537-42. 1964.

54. Reid, R. L. and G. A. Jung. Factors affecting the intake and palatability of forages by sheep. Proc. 9th Int. Grassland Congress, Brazil. 1965.

55. The influence of fertilizer treatment on the intake, digestibility and palatability of tall fescue hay. J. Animal Sci., 24: 615-625. 1965.

56. Richards, C. R., G. F. W. Haenlein, M. C. Calhoun, J. D. Connolly and H. G. Weaver. Date of cut vs. the combination of crude fiber and crude protein as estimators of forage quality. J. Animal Sci., 21: 844-47. 1962.

57. Robinson, R. R., W. H. Pierre and R. A. Ackerman. A comparison of grazing and clipping for determining the response of permanent pastures to fertilization. J. Am. Soc. Agron., 29: 349-58. 1937.

58. Robinson, R. R. Soil properties determining the botanical composition of pastures in West Virginia. J. Agr. Res., 54: 877-97. 1937. 
59. Robinson, R. R. and W. H. Pierre. Response of permanent pastures to lime and fertilizers ( 1930 to 1936). W. Va. Agr. Expt. Sta. Bull. 289. 1938.

60. Rumery, M. G. A. and R. E. Ramig. Irrigated Sudangrass for dairy cows. Neb. Agr. Expt. Sta. Bull. SB472. 1962.

61. Rusoff, L. L., A. S. Achacoso, C. L. Mondart, Jr., and F. L. Bonner. Relationship of lignin to other chemical constituents in Sudan and millet forages. La. Agr. Expt. Sta. Bull. 542. 1961.

62. Schaller, F. W., G. G. Pohlman, H. O. Henderson and R. A. Ackerman. Pasture fertilization experiments at Reymann Memorial Farms. W. Va. Agr. Expt. Sta. Bull. 324. 1945.

63. Stallcup, O. T. and G. V. Davis. Influence of stage of maturity on the nutritive value of Sudangrass. J. Dairy Sci., 46: 366. 1963.

64. Sullivan, E. F. Effect of temperature and phosphorus fertilization on the yield and composition of Piper Sudangrass. Agron. J., 53: 357-58. 1961.

65. Sullivan, J. T. Chemical composition of forages in relation to digestibility by ruminants. U.S.D.A. Agr. Res. Ser. Bull. 34-62. 1964.

66. Swanson, C. O. Hydrocyanic acid in Sudan grass and its effect on cattle. J. Am. Soc. Agron., 13: 33-36. 1921.

67. Tippit, O. J. and J. H. Jones. Soil conservation management system for beef production in the blacklands of Texas. Tex. Agr. Expt. Sta. Misc. Publ. 90. 1953.

68. Van Keuren, R. W. and W. W. Heinemann. Annual and perennial irrigated pastures and progesterone-estradiol implants for lamb production. Wash. Agr. Expt. Sta. Bull. 641. 1963.

69. Van Soest, P. J. Use of detergents in the analysis of fibrous feeds. II. A rapid method for the determination of fiber and lignin. A.O.A.C. 46 (5): 829-32. 1963.

70 . Annual report to NE-24 Technical Committee. 1963.

71. Van Wyk, H. P. D., S. A. Oosthuizen and I. D. Basson. The nutritive value of South African feeds. Union of S. Africa Dept. of Agr. Sci. Bull. 298. 1951. 
APPENDIX 
TABLE 1

Average Monthly Maximum and Minimum Temperatures and Monthly Precipitation at Morgantown, Point Pleasant, Wardensville, Reedsville and Martinsburg, West Virginia

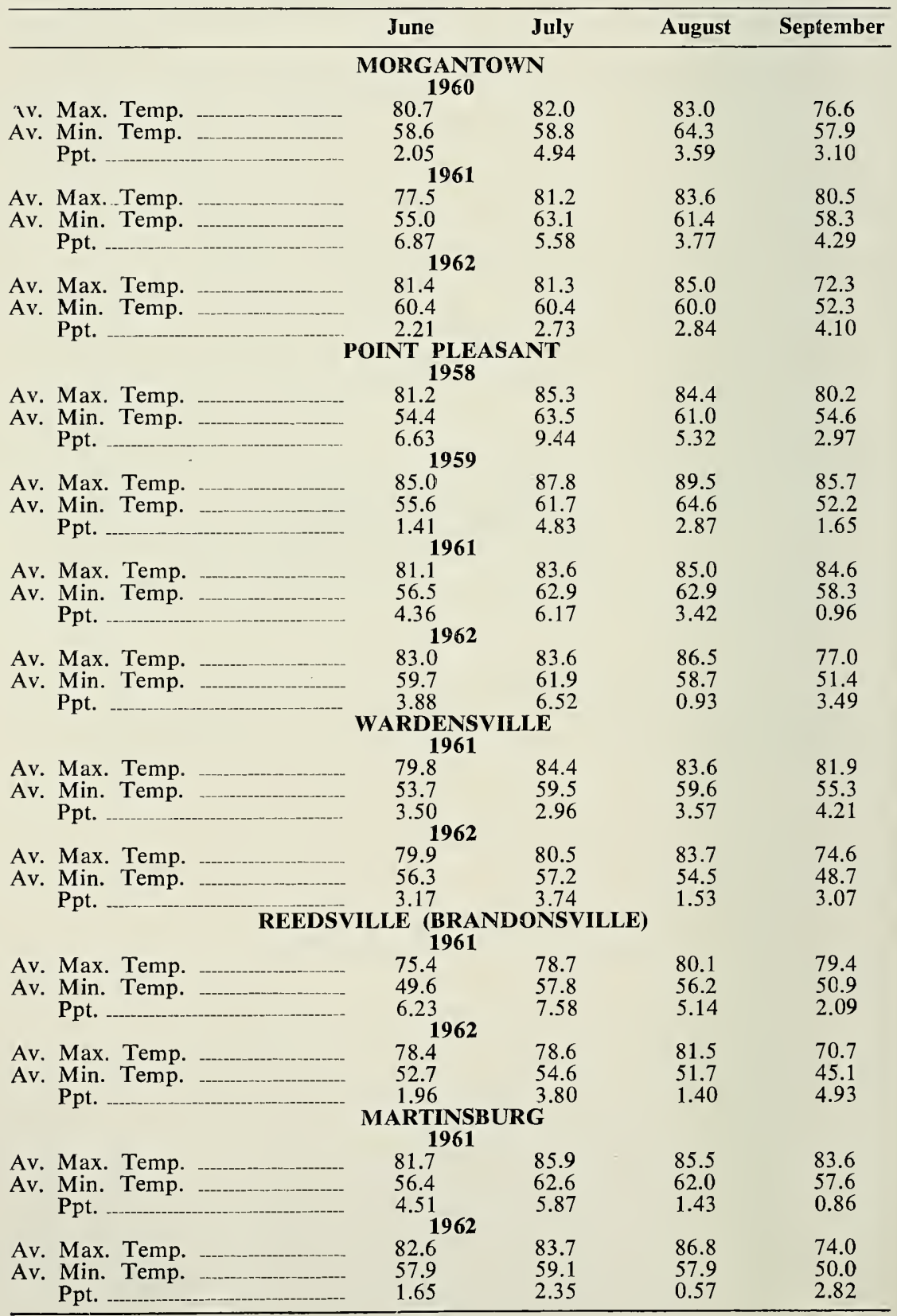


TABLE 2

Source of Plant Materials for Experiments

\begin{tabular}{|c|c|}
\hline Variety* & Type* \\
\hline Grazer-_-_- & $\begin{array}{c}\text { Sudangrass-Sorghum Hybrid Asgrow Seed Company of Texas } \\
\text { San Antonio, Texas }\end{array}$ \\
\hline Hi dan 37,38 & $\begin{array}{l}\text { Sudangrass-Sorghum Hybrid... Frontier Hybrids, Inc. } \\
\text { Scott City, Kansas }\end{array}$ \\
\hline Sudax SX-11 & $\begin{array}{l}\text { Sudangrass-Sorghum Hybrid -- Dekalb Agricultural Assoc., Inc. } \\
\text { Dekalb, Illinois }\end{array}$ \\
\hline 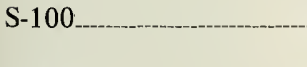 & $\begin{array}{l}\text { Sudangrass-Sorghum Hybrid... C. M. Volkman and Company } \\
\text { San Francisco, California }\end{array}$ \\
\hline Almum & $\begin{array}{ll}\text { unknown origin } & \text { New Mexico Seed Farms, Inc. } \\
\text { Clovis, New Mexico }\end{array}$ \\
\hline Lindsey $77 F_{-}$ & $\begin{array}{l}\text {-Sudangrass-Sorghum Hybrid_-- Lindsey Seed Co. } \\
\text { Lubbock, Texas }\end{array}$ \\
\hline Sweet Sioux & $\begin{array}{l}\text { Sudangrass-Sorghum Hybrid _. Paymaster Seed Farms } \\
\text { Plainview, Texas }\end{array}$ \\
\hline Suhi-1 & Sudangrass Hybrid _ USDA \\
\hline Sorghum Almum & Sorghum-johnsongrass Hybrid USDA \\
\hline Tift___________- & Sudangrass_ USDA \\
\hline Piper______- & Sudangrass___ USDA \\
\hline Greenleaf & Sudangrass_____._. USDA \\
\hline Piper x Redlan & Sudangrass-Sorghum Hybrid _._USDA \\
\hline Piper x Tex. Bk. Kafir_- & Sudangrass-Sorghum Hybrid USDA \\
\hline Piper x Gr.g. 3056 & Sudangrass-Sorghum Hybrid_._.USDA \\
\hline Piper x Gr.g. 3054 & Sudangrass-Sorghum Hybrid _...USDA \\
\hline Sweet x Gr.g. 3056 & Sudangrass-Sorghum Hybrid _.._USDA \\
\hline Sweet x Redlan & Sudangrass-Sorghum Hybrid _..USDA \\
\hline Sweet x Tex. Bk. Kafir & Sudangrass-Sorghum Hybrid USDA \\
\hline Sweet x Gr.g. 3054 & Sudangrass-Sorghum Hybrid _... USDA \\
\hline Piper x S. propinquum & Sudangrass-Sorghum Hybrid _... USDA \\
\hline
\end{tabular}

*None of the materials had a perennial growth habit. 


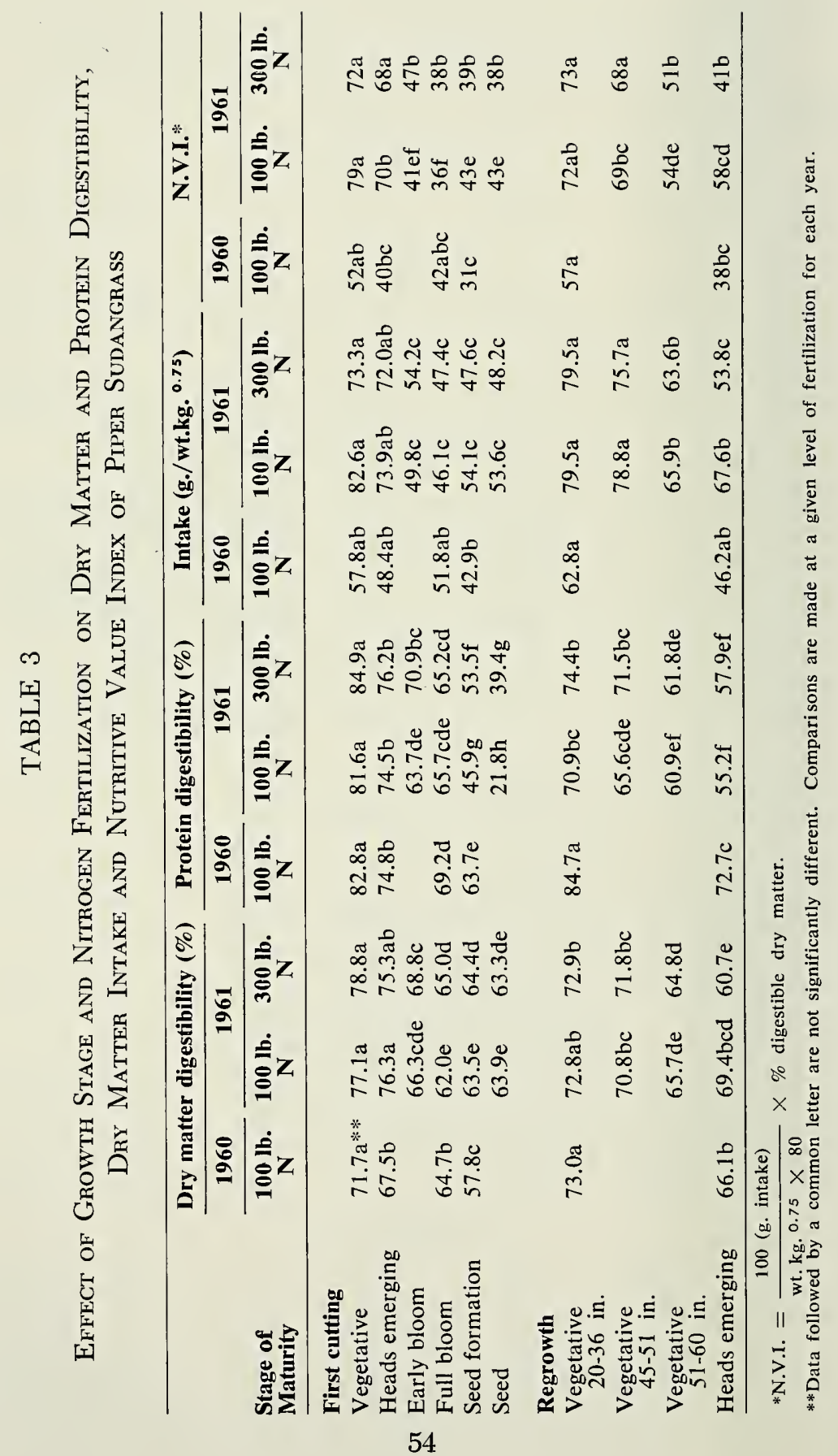




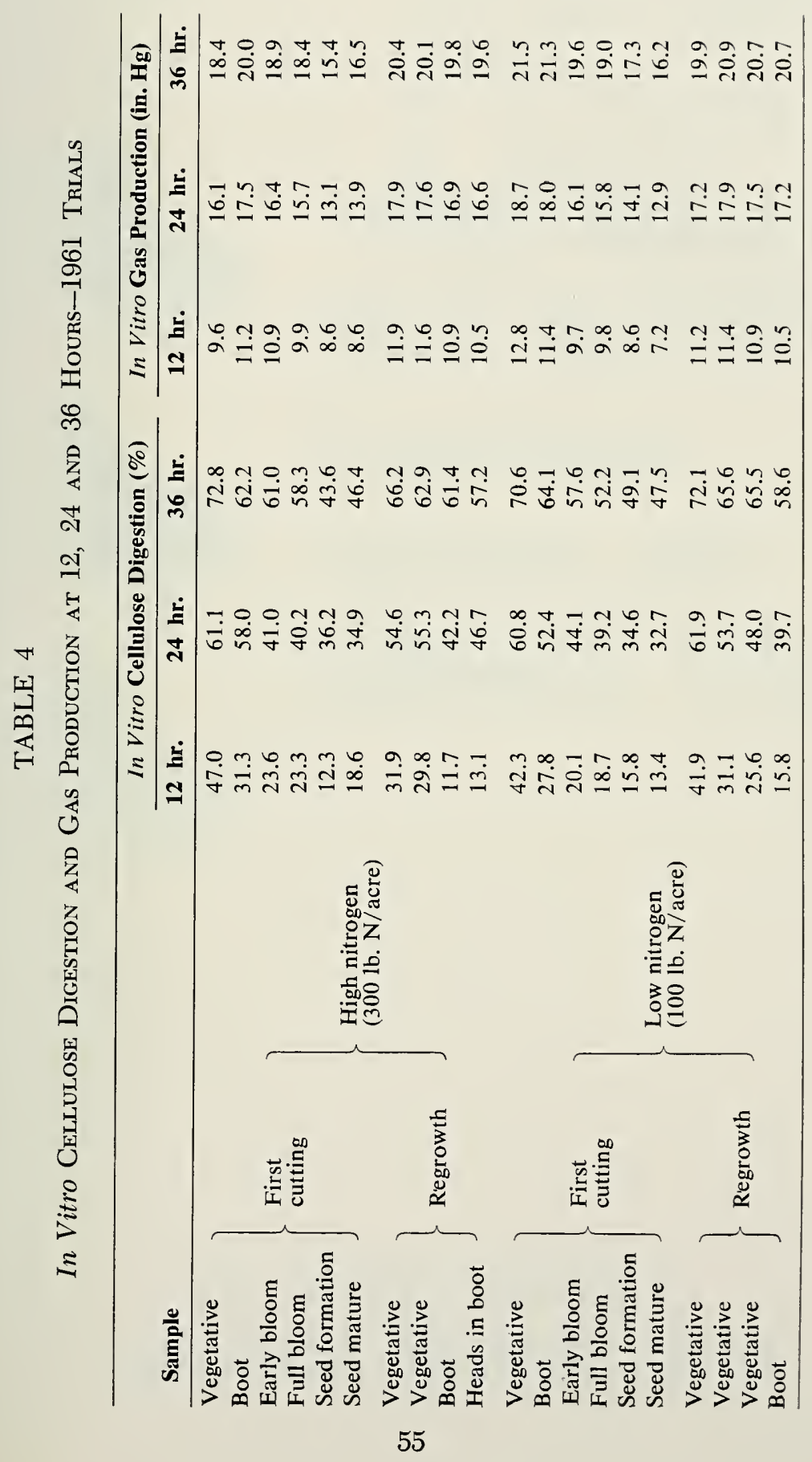




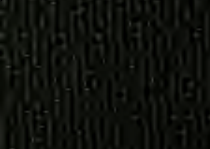

